\title{
A Current Bibliography of Canadian Church History
}

\section{Brian F. Hogan}

Volume 46, 1979

URI : https://id.erudit.org/iderudit/1007120ar

DOI : https://doi.org/10.7202/1007120ar

Aller au sommaire du numéro

Éditeur(s)

Les Éditions Historia Ecclesiæ Catholicæ Canadensis Inc.

ISSN

0318-6172 (imprimé)

1927-7067 (numérique)

Découvrir la revue

Citer ce document

Hogan, B. F. (1979). A Current Bibliography of Canadian Church History.

Sessions d'étude - Société canadienne d'histoire de l'Église catholique, 46, 99-137.

https://doi.org/10.7202/1007120ar

Tous droits réservés @ Les Éditions Historia Ecclesiæ Catholicæ Canadensis Inc., 1979
Ce document est protégé par la loi sur le droit d'auteur. L'utilisation des services d’Érudit (y compris la reproduction) est assujettie à sa politique d'utilisation que vous pouvez consulter en ligne.

https://apropos.erudit.org/fr/usagers/politique-dutilisation/ 


\section{A Current Bibliography of Canadian Church History}

NOTE : Within each section works are set out in alphabetical order under the name of the author. In sections 5, 6 and 8, however, the arrangement is first alphabetical by subject, i.e., communion, place or person. Items are not repeated, but at the beginning of each section reference is given to relevant items in earlier or later sections.

$$
\begin{aligned}
& \text { Brian F. Hogan, C.S.B. } \\
& \text { St. Basil's College } \\
& \text { Toronto, Ontario. }
\end{aligned}
$$

List of Abbreviations :

$B C G$

Cahier

CES

$\mathrm{CHR}$

CSCH Papers

DissAbs

HPCH

$H S$ / SH

$J C A H / A A C$

$J C S / R E C$

$N S H Q$

RHAF

RUO
British Columbia Genealogist

La Société historique acadienne, Cahier

Canadian Ethnic Studies

Canadian Historical Review

Canadian Society of Church History, Papers

Dissertation Abstracts

The Canadian Historical Association / La Société historique du Canada, Historical Papers / Communications historiques

Histoire Sociale / Social History

Journal of Canadian Art History / Annales de l'art canadien

Journal of Canadian Studies / Revue d'études canadiennes

Nova Scotia Historical Quarterly

Revue d'histoire de l'Amérique française

Revue de l'Université d'Ottawa 
Sessions d'étude /

Study Sessions

TRSC / MSC

UCCA

$U H R / R H U$
La Société oanadienne d'histoire de l'Église / The Canadian Catholic Historical Association - Sessions d'étude / Study Sessions

Transactions of the Royal Society of Canada/Mémoires de la Société royale du Canada

United Church of Canada, Archives

Urban History Review' / Revue d'histoire urbaine 


\section{GUIDES : bibliographies, descriptions of sources}

See : 4. "Bibliography ..."

Artibise, Alan F.J., Western Canada Since 1870: A Select Bibliography and Guide. Vancouver : U.B.C. Press, 1978. Pp. 312.

Côté, André, "Sources manuscrites conservées au Saguenay-Lac Saint-Jean", Archives, 74,2 (1974) 22-34.

Demers, Jean-Maurice et al.. Archives du Séminaire de Sherbrooke. Coll. Archives Service. Sherbrooke: le Séminaire, 1976. 2 vols.

Dictionnaire bibliographique du Canada. Vol. IX - de 1861 à 1870. Québec : U. Laval, 1977. Pp. XIII, 1057.

Dronne, N.-E., Inventaire chronologique dés livres, brochures, journaux et revues puhliés en langue anglaise dans la province de Québec, depuis l'établissement de l'imprimerie en Canada jusqu'à nos jours - 1764-1906. Québec, 1907. New York: AMS Press, 1974. Pp. 228.

Doyle-Frenière, Murielle, "Les Archives de la ville de Québec". Urban History Review/Revue d'histoire urbaine, 1, 77 (1977) 33-37.

GaGNON, Serge, "The Historiography of New France, 1960-1974". JCS/REC. 13, 1 (1978) 80-99.

GoerTz, Richard O.W., "University Research on Jewish-Canadians : Second Supplement”, Canadian Ethnic Studies, V, 1-2 (1973) 207-212.

GoerTZ, Richard O.W. and Alexander MaLycky, "German-Canadian Church History : Part II. Individual Congregations : A Preliminary Bibliography”. Canadian Ethnic Studies. V, 1-2 (1974) 95-124.

Gourd, Benoît-Beaudry et Denise LavalléE, Bibliographie de l'Abitibi-Témiscamingue. Deuxième supplément, Université du Québec, Centre d'études universitaires dans l'Oucst québécois. Rouyn: Centre de documentation régionale, 1977. Pp. 202.

Guide des sources d'archives sur le Canada français au Canada. Ottawa : Archives publiques du Canada. 1975. Pp. 195.

Hogan, Brian F., C.S.B., "A Current Bibliography of Canadian Church History". Study Sessions, 45 (1978) 101-141.

Klingelsmith, Sharon and Kenneth SPRinger, "A Bibliography of the Writings of Melvin Gingerich". The Mennonite Quarterly Review, 52, 2 (1978) 170-182.

List of Publications, Leeds and Grenville Genealogical Society. (Saint Lawrence Court. R.R. \#1, Prescott, Ontario, I K0E 1T0).

List of Publications, Ontario Genealogical Society, Ottawa Branch. (P.O. Box 8346, Ottawa, Ontario, K1G 3H8).

Livingstone, Elizabeth, ed., The Concise Oxford Dictionary of the Christian Church. New York : Oxford U. Press, 1977. Pp. vi, 570. 
Mallea, J.R. and L.M. Philip, "Canadian Cultural Pluralism and Education : A Select Bibliography”, Canadian Ethnic Studies, VIII, 1 (1976) 81-88.

Malycky, Alexander, "University Research on Ukrainian-Canadians", Canadian Ethnic Studies, V 1-2 (1973) 271-274.

MCLaren, Duncan, comp., Ontario Ethno-Cultural Newspapers 1835-1972: An Annotated Checklist. Toronto and Buffalo: U. of Toronto Press, 1977. Pp. 234.

Mika, Nick and Helma, comp., Places in Ontario: Their Name Origins and History. Part I:A to E. Belleville, Ont.: Mika Publishing Co., 1977. Pp. 60, ill.

PINARD, Yolande, "Des archives de femmes pour le début du siècle", Bulletin du Regroupement des chercheurs en histoire des travailleurs québécois. 3, 2 (1976) 24-39.

Provost, Honorius, "Les Archives du Séminaire de Québec", Archives, 74, 2 (1974) 12-21.

TAPPer, Lawrence F., A Guide to Sources For the Study of Canadian Jewry. Ottawa : P.A.C., National Ethnic Archives, 1978. Pp. 51.

Tennyson, Brian, ed., Cape Breton: A Bibliography. Halifax : Nova Scotia Department of Education, 1978. Pp. vi, 114.

\section{SOURCES}

BÉlanger, Léonidas, "Les mariages de la région (Chicoutimi)", Saguenayensia, 19,1 (1977) $11-14 ; 19,2$ (1977) $35-38 ; 19,3$ (1977) $65-68 ; 19,4$ (1977) $99-102 ; 19,5-6$ (1977) $127-130 ; 20,1$ (1978) $11-14 ; 20,2$ (1978) $37-40 ; 20,3-4$ (1978) $77-80 ; 20,5$ (1978) 121-124; (SaintFrançois-Xavier de Chicoutimi, 1899-1910).

Bohdan, F., Slovnyk Ukrains'kykh Prizvyshch u Kanadi. (Dictionary of Ukrainian Surnames in Canada). Winnipeg and Vancouver: Onomastic Commission of VAN and Canadian Institute of Onomastic Sciences, 1974. Pp. 354.

Britnell, W.E., comp., County Marriage Registers of Ontario, Canada, 1859 1969, Vol. I - Index to Peel County. Agincourt: Generation Press, 1979. Pp. 50.

Charbonneau, Hubert et Raymond Roy, "Généalogie, démographie et registres paroissiaux", Mémoires de la Société généalogique canadienne-française, 26,41 (janv.-mars, 1976) 23-36.

Gaboury, Jean, "Mariages - Hôpital du Sacré-Cœur (paroisse N.-D. du SacréCœur) (1874-1892), et Hôtel-Dieu du Sacré-Cœur de Jésus (paroisse du Sacré-Cœur de Jésus) (1892-1939)", L'Ancêtre, 8,10 (1977) 431-439.

-. "Mariages - Hôpital Saint-Michel-Archange (paroisse Saint-Michel-Archange), 1896-1975", L'Ancêtre, 4,2 (1976) 43-52. 
Houle, Hubert A., comp., Mariages de la paroisse Saint-Grégoire-de-Naziance de Buckingham, 1863-1975. Vanier, Ont. : Centre de Généalogie, 1976. Pp. 234.

-. Mariages de Saint-Charles et Sacré-Cour, Ottawa et Vanier, de la fondation de la paroisse jusqu'en 1975. Vanier, Ont.: Centre de Généalogie, 1976.

-. Répertoire des mariages de Lafontaine, Penetanguishene, Perkinsfield. Vanier, Ont. : Centre de Généalogie, 1976. Pp. 227.

Matériaux pour l'histoire des institutions universitaires de philosophie au Québec. Collection "Études sur le Québec", Cahiers de l'ISSH, no. 4, tome 1 (551p), tome II (198p). Québec : U. Laval, 1976.

Poirier, Armand, "Les Frères du Sacré-Coeur canadiens et les frères d'origine canadienne-française par leurs parents", L'Ancêtre, 2,5 (1976) 223-278.

Provencher, Gérard-E., "Baptêmes de Notre-Dame-de-Québec, 1621-1700 (suite)", L'Ancêtre, 2,6 (1967) 291-310; 10 (juin, 1976) 459-478; 3,4 (1976) $151-170 ; 7$ (mars, 1977) 285-304.

Racine, Denis, "Registres de Sainte-Anne-de-Beaupré - baptêmes et sépultures - 1657-1700", L'Ancêtre, 3,8 (1977) 331-338; 4,1 (1977) 7-10 ; 3 (nov., 1977) 83-89; 4 (déc., 1977) 133-137.

Records of the Christian Reformed Church, Nobleford, Alta., relating to immigration (Dutch). Calgary, Glenbow - Alberta Institute Archives.

Records of the Crossfield (Alta.) United Church 1947-1972. Edmonton. Provincial Archives of Alberta.

Records of the Edmonton Hebrew Association (1906-58). Edmonton, Archives of Alberta.

Records of the Edmonton Hebrew School Talmud Torah, 1968-1976. Edmonton, Provincial Archives of Alberta.

Records of the Hebrew National Association (Folks Farein), Toronto, 19241970. Toronto, Canadian Jewish Congress Central Region Archives.

Records and papers of the Rev. Egerton Ryerson Young, northern missionary and author (1869-1915). Toronto: Archives of Ontario.

Records of the Pioneer Women's Organization, Hamilton, 1931-1935. Toronto, Canadian Jewish Congress Central Region Archives.

Records of the Protestant Children's Orphanage. Ottawa, City Archives.

Records of the Quakers' Yonge Street Monthly Meetings, c. 1807-13. Toronto, Archives of Ontario.

Records of the Toronto Hebrew Benevolent Society. Toronto, Canadian Jewish Congress Central Region Archives.

Records of the Western Canada Synod, Lutheran Church in America (c. 19021972). Edmonton, Archives of Alberta. 
Scallen, Peter Thomas, "Mariages de la paroisse St-Vincent, Ste-Foy, Québec, 1964-1970”, L'Ancêtre, 3,4 (1976) 179-184.

Sermons, correspondence and essays, Rev. J.C. Bowen, and his father-in-law, Rev. G.L. Oliver (c. 1882-1942). Edmonton : Archives of Alberta.

\section{GENERAL WORKS}

Baum, Gregory, The Social Imperative: Essays on the Critical Issues that Confront the Christian Churches. New York : Paulist Press, 1979. Pp. v, 254.

Beaulieu, André et Jean Hamelin, La Presse Québécoise des origines à nos jours. III : 1880-1895. Québec: U. Laval, 1977. Pp. xv, 421.

BÉDARD, Marc-André, "La présence protestante en Nouvelle-France", $R H A F$, 31,3 (1977) 325-350.

CARTWRIGHT, D.G., "Ecclesiastical Territorial Organization and Institutional Conflict in Eastern and Northern Ontario, 1840 to 1910". C.H.A. Historical Papers, 1978. Pp. 176-199.

Cole, Harris R., Two Societies: Life in Mid-Nineteenth Century Quebec. Toronto: McClelland and Stewart, 1976. Pp. 63.

Coward, Harold and Leslie Kawamura, eds., Religion and Ethnicity. Water100 : Wilfrid Laurier U. Press, 1978. Pp. 181.

FourniER, Rodolphe, N.P., Lieux et monuments historiques du sud de Montréal. Saint-Jean, P.Q. : Éditions du Richelieu, Ltée, 1976. Pp. 316.

GroulX, Lionel, Notre grande aventure: l'Empire français en Amérique du Nord (1535-1760). Coll. Bibliothèque canadienne-française : histoire et documents. Montréal : Fides, 1958, 1976. Pp. 299.

Hamelin, Jean, dir., Histoire du Québec. Coll. Univers de la France et des pays francophones. Toulouse : Édouard Privat, 1976. Pp. 536.

Klassen, Henry C., ed., The Canadian West: Social Change and Economic Development. Calgary : Comprint Publishing Co., 1977. Pp. 220.

LitTell, Franklin H., The Macmillan Atlas History of Christianity. New York : Macmillan Publishing Co., 1976. Pp. xii, 176.

MacEwan, Grant, ... and Mighty Women Too: Stories of Notable Western Canadian Women. Saskatoon: Western Producer Prairie Books, 1975. Pp. 307, ill.

Meidhardt, Wilfred, Fenianism in North America. University Park : Pennsylvania State U. Press, 1975. Pp. xi, 164,4.

Miller, J.R., Equal Rights : The Jesuits' Estates Act Controversy. Montreal : McGill-Queen's U. Press, 1979. Pp. 236.

Monière, Denis, Le Développement des idéologies au Québec des origines d nos jours. Québec : Éditions Québec-Amérique, 1977. 
Nolte, William Michael, The Irish in Canada, 1815-1867. Ph.D. Thesis, U. of Maryland, 1975. Pp. 399.

Ouellet, Fernand, Le Bas Canada, 1791-1840. Ottawa: Éditions de 1'U. d'Ottawa, 1976. Pp. 541.

Robeson, Virginia R. et al., New France, 1713-1760 : Documents in Canadian History. Toronto : Ontario Institute for Studies in Education, 1977. Pp. 87.

Roy, Raymond, Yves Landry et Hubert Charbonneau, "Quelques comportements des Canadiens au XVII ${ }^{\circ}$ siècle d'après les registres paroissiaux", RHAF, 31,1 (juin, 1977) 49-74.

Slater, Peter, Religion and Culture in Canada. Waterloo : Wilfrid Laurier U. Press, 1972. Pp. 566.

StEwart, Alexander McGinn, French Pioneers in North America. New York State Archaelogical Association, 1958-59. Millwood: Kraus Reprint Co., 1976. Pp. 16-38.

Teboul, Victor, "Antisémitisme : mythe et images du Juif au Québec (essai d'analyse)", Voix et images du pays, 9 (1975) 87-112. (1920-1940).

\section{CHURCH HISTORY : philosophy, principles}

"Bibliography of Works on the Philosophy of History 1969-1972 (1966-1968 Addenda)", History and Theory, Beiheft 13, 1974.

Dawson, Christopher, Religion and World History. James OLIVER and Christina Scott, eds. Garden City, N.Y. : Image Books, 1975. Pp. 375.

Delumeau, Jean, "Problèmes méthodologiques fondamentaux sur l'histoire des mentalités religieuses dans l'Occident moderne, Ricerche di Storia Sociale e Religiosa, 4 (1975) 373-397.

Grant, George, The Wood Lectures: English-Speaking Justice. Sackville, N.B. : Mount Allison University, 1978. Pp. 112.

KING-Farlow, John, The Challenge of Religion Today. New York: Science History Publications, 1976. Pp. 205. (Reflections of Canadian Philosophers).

LaNGlors, Claude, "Des Études d'histoire ecclésiastique locale à la sociologie religieuse historique. Réflexions sur un siècle de production historiographique", Revue d'Histoire de l'Église de France, LXII (juillet-décembre, 1976 ) 329-347.

Marsden, George and Frank Roberts, A Christian View of History? Grand Rapids : William B. Eerdmans Pub. Co., 1975. Pp. 201.

McPartland, Thomas J., Horizon Analysis and Historiography: The Contribution of Bernard Lonergan Toward a Critical Historiography. Ph.D. Thesis, U. of Washington, 1976. Pp. 642. Diss. Abs. 76-25, 433. 
Olmsted, Richard Henry, Christian Beliefs, History and Historical Study.

Ph.D. Thesis, Yale U., 1975. Pp. 359. Diss. Abs. 76-14, 584.

Petersen, Rev. William Herbert, Frederick Denison Maurice as Historian: An Analysis of the Character of Maurice's Unsystematic Theology, Attempting to Disclose a Method Capable of Reconciling Secular and Ecclesiastical Historiography. Ph.D. Thesis, Graduate Theological Union, 1976. Pp. 493. Diss. Abs. 76-23, 462.

SpITz, Lewis W., "History : Sacred and Secular", Church History, 47, 1 (1978) 5-23.

\section{THE COMMUNIONS}

\section{A. General}

Challice, Isabelle and Grant Curtis, Spirit of the Hills. (Brief reference to a number of Protestant Churches and organizations in Ontario centres such as Peterborough, Cavan, Janetville, etc.) [sl.: s.n.], 1977. Pp. 178. Toronto, Presbyterian Archives.

CLIFFord, N.K., "The Origins of the Church Union Controversy", Journal of the Canadian Church Historical Society, 18, $2-3$ (1976) 34-52.

De Baillehache, Sr. Marie Noëlle, N.D.S., "Où en sont les relations entre chrétiens et juifs au Canada, aujourd'hui?", L'Église canadienne, 8,3 (1975) 84-86.

Vanoene, W.W.J., Inheritance Preserved: The Canadian Reformed Churches in Historical Perspective. Winnipeg: Premier Print, 1975. Pp. 280, ill.

\section{B. Particular Communions}

Anglican. See : 6A. Toronto-Masters ; 8. Bickersteth.

GABBeRT, Mark, "Anglicans and Social Justice", Queen's Quarterly, 85,1 (1978) 191-202.

Baptist. HunTER, Gordon W., North American Baptists and International Issues, 1935-1945. M.A. Thesis. U. of New Brunswick, 1977.

Bible Christian Church. Brooks, W.H., "The Bible Christian Church in the West", Prairie Forum, 1,1 (1976) 59-67.

Buddhist. Kawamura, Leslie, "Changes in the Japanese True Pure Land Buddhism in Alberta, A Case Study: Honpa Buddhist Church in Alberta", in: H. CoWARD and L. KaWAMURA, eds., Religion and Ethnicity. Waterloo: Wilfrid Laurier U. Press, 1978. Pp. 37-56.

-. "The Historical Development of the Buddhist Churches in Southern Alberta", in: Religion and Culture in Canada. Waterloo : Wilfrid Laurier U. Press, 1977. Pp. 491-506. 
Christian Reformed. See : 2. Records of the Christian Reformed...; 8B. Beynon-Cook.

Congregationalism. KenYon, John P.B., "The Development of Congregationalism in Early Nineteenth-Century Ontario", The Canadian Society of Church History, Papers, 1978. Pp. 11-25.

Doukhobor. See : 11B. Lyons.

Bradley, Kathleen J., Factionalism in the Doukhobor Movement. M.A. Thesis, U. of Calgary, 1976. Pp. vi, 89.

BUyniak, Victor, "Tolstoy and the Doukhobors", Chelsea Journal, 4,3 (MayJune, 1978 ) 151-155.

Gale, Donald T. and Paul M. Koroscil, "Doukhobor Settlements : Experiments in Idealism", Canadian Ethnic Siudies, 9,2 (1977) 53-7i.

Greig, Hugh and Terry McLean, The Hope and the Promise: The Tender, Tragic and Often Brutal Story of the Doukhobors. Langley, B.C. : Stagecoach Publishing, 1977. Pp. 176.

McCormick, Patricia L., "The Doukhobors in 1904", Saskatchew'an History, 31,1 (1978) 12-19.

Mealing, F.M., Doukhobor Life : A Survey of Doukhobor Religion, History and Folklife. Doukhobor Historical Society, Castlegar, B.C.: Cotinneh Books, 1975. Pp. 67, ill.

Minden, Robert, "'Strangers on the Earth': Meetings with the DoukhoborCancidians in British Columbia", Sound Heritage, 5,2 (1976) 19-34.

Tarasoff, Koozma, Traditional Doukhobor Folkways : An Ethnographic and Biographic Record of Prescribed Behaviour. Canadian Centre for Folk Culture Studies, Paper No. 20. Ottawa : National Museums of Canada, 1977. Pp. xxviii, 396.

Evangelical Lutheran. Evenson, George O., Adventuring for Christ: The Story of the Evangelical Lutheran Church of Canada. Calgary : Foothills Lutheran Press, 1974. Pp. xi, 301.

Hutterite. See : 11B. MacDonald.

Evans, Simon, "Spatial Bias in the Incidence of Nativism : Opposition to Hutterite Expansion in Alberta", Canadian Ethnic Studies, vi, 1-2 (1974) $1-16$.

Ryan, John, The Agricultural Economy of Manitoba Hutterite Colonies. Toronto: McClelland and Stewart, 1977. Pp. 306.

Jewish. See : 1. Goertz - "University Research ..."; Tapper; 2. Records of the Edmonton Hebrew...; Records of the Hebrew...; Records of the Pioneer; Records of the Toronto Hebrew Benevolent...; 3. Teboul; 11B. Shaffir ; 11C. Ritchtik.

ARnold, A.J., "Jewish Pioneer Settlements", The Beaver, 306,2 (1975) 20-26. ("William Kurelek Paintings", 27-29). 
BÉDARD, Émile, Les amitiés judéo-chrétiennes de Québec. Thèse M.A., U. d'Ottawa, 1972.

Rome, David, Clouds in the Thirties: On Anti-Semitism in Canada 1929-1939. Montreal : David Rome, 6055 Mountain Sights, 1977.

Weinfeld, Morton, "A Note on Comparing Canadian and American Jewry", The Journal of Ethnic Studies, 5,1 (1977) 95-103.

Lutheran. See : 2. Records of the Western

Mennonite. See : 1. Klingelsmith.

Driedger, Leo, J. Winfield Fretz and Donovan E. Smucker, "A Tale of Two Strategies : Mennonites in Chicago and Winnipeg". The Monnonite Quarterly Review, 52,4 (1978) 294-312.

EpP, Frank, "The Mennonite Experience in Canada", in: H. Coward and L. Kawamura, eds., Religion and Ethnicity. Waterloo: Wilfrid Laurier U. Press, 1978. Pp. 21-36.

-.Mennonite Peoplehood: A Plea for New Initiatives. Waterloo : Conrad Press, 1977. Pp. 120.

FrIesen, Richard J., "Saskatchewan Mennonite Settlements : The Modification of an Old World Pattern", Canadian Ethnic Studies, 9,2 (1977) 72-90.

Hamm, Peter M., Continuity and Change Among Canadian Mennonite Brethren, 1925-1975. A Study of Sacralization and Secularization in Sectarianism. Ph.E. Thesis. McMaster U., 1978.

JanZen, Adina and Winnie Dueck, ed., History of B.C. Mennonite Women in Mission, 1939-1976. Chilliwack, B.C. : Mennonite Women in Mission. 1976. Pp. 100.

Schlabach, Theron F., "The Humble Become 'Aggressive Workers' : Mennonites Organize for Mission 1880-1910", The Mennonite Quarterly Review, 52,2 (1978) 113-126.

ToEws, Paul, ed., Pilgrims and Strangers: Essays in Mennonite Brethren History. Fresno, Calif. : Center for Mennonite Brethren Studies, 1977. Pp. 183.

Methodist. Manning, Harry, "The Changing Mind-Set of Canadian Methodism. 1884-1925", Canadian Methodist Historical Society, Papers, 1978. Pp. 24. (Available, U.C.C.A.).

Smyth, Elizabeth M., "Centenary Methodist Church : A Study of the Congregation and Lay Membership, 1899", The Canadian Methodist Historical Society, Papers, 1978. Pp. 15,2. (Available, U.C.C.A.).

Moslem. Faнti, Azgar, "The Arab Moslem Community in the Prairie City", Canadian Ethnic Studies, v. 1-2 (1973) 409-426.

Barclay, Harold, "The Muslim Experience in Canada", in: H. Coward and L. Kawamura, eds., Religion and Ethnicity. Waterloo: Wilfrid Laurier U. Press, 1978. Pp. 101-114. 
Haddad, Yvonne Yazbeck, "Muslims in Canada : A Preliminary Study", in:

H. Coward and L. Kawamura, eds., Religion and Ethnicity. Waterloo:

U. Press, 1978. Pp. 71-100.

Presbyterian. See : 6A. Cape Breton - Mackinnon; 7. Edinborough.

Quakers. See : 2. Records of the Quakers ...

KeYES, Jane, "Marriage Patterns Among Early Quakers". Nora Scotia Historical Quaterly, 8,4 (1978) 299-308.

Reformed Churches. Vanoene, W.W.J., Inheritance Preserved: The Canadian Reformed Churches in Historical Perspective. Winnipeg: Premier Print, 1975. Pp. 280.

Rome, Churches in Communion with - Latin. See : 11E. Mawer.

Champagne, Gérard, Nos Gloires. Montréal : Les Éditions Jésus-Marie et Notre Temps, 1976. Pp. 217. (Brief hagiographies of outstanding church people.)

"La congrégation des religieuses de Jésus-Marie al Canada depuis 1855", L'Ancêtre, 3,5 (1977) 195-235. (Répertoire des membres).

CôTÉ, André, L'Ordre de Citeaux et son établissement dans la province de Québec, depuis la révolution française jusqu'à 1935. M.A. Thesis, U. Laval, 1972.

"Frères maristes canadiens de la province de Lévis, Frères maristes défunts (Province du Canada), les frères maristes au Québec", L'Ancêtre, 3,8 (1977) 339-350.

Gingras, Robert Edmond, "Les Frères des écoles chrétiennes", L'Ancêtre, 2.7 (1976) 320-342.

Hurtubise, P., G. Lesage, J.-P. Wallot et als., Le laïc dans l'Église canadienne-française de 1830 à nos jours. Collection: Histoire religieuse du Canada. Montréal : Fides, 1972. Pp. 223.

JEAN, Sr. Marguerite, S.C.I.M., Évolution des communautés religieuses de femmes au Canada de 1639 à nos jours. Collection: Histoire religieuse du Canada. Montréal : Fides, 1977. Pp. 330.

Keane, Br. J.P., Journey Into a New Century. (s.n.: s.1.), 1977. Pp. 48. (Christian Brothers in North America).

LEMIEUx, L., L'établissement de la première province ecclésiastique au Canada 1783-1844. Collection: Histoire religieuse du Canada. Montréal: Fides, 1968. Pp. 559.

Litalien, R., Le Prêtre québécois à la fin du XIX $X^{e}$ siècle. Collection : Histoire religieuse du Canada. Montréal : Fides, 1970. Pp. 219.

Maxwell, Grant, "Faith Experiences in Transition Among Canadian Catholics", in: H. Coward and L. KaWamura, eds., Religion and Ethnicity. Waterloo: Wilfrid Laurier U. Press, 1978. Pp. 115-134.

Morrisey, Francis G., The Juridical Status of the Catholic Church in Canada 1534-1840. Ph.D. Thesis, Ottawa U., 1972. 
Rome, Churches in Communion with, Ukrainian Greek Catholic.

Baran, Anna Maria, Ukrainian Catholic Churches of Saskatchewan. (Album Fund, 214 Ave. M. South, Saskatoon). Pp. 430.

Goresky, Isidore, trans., "Minutes of the Founding of One of the First Ukrainian Greek Catholic Churches in Alberta, March 1890". Canadian Ethnic Studies, VI, 1-2 (1974) 67-70.

United Church. Harrison, Marilyn Joan, The Social Influence of the United Church of Canada in British Columbia, 1930-1948. M.A. Thesis. U. of British Columbia, 1975. Pp. v, 281. Canadian thesis on microfiche. No. 25176.

Mitsur, Tadashi, The Ministry of the United Church of Canada Amongst Japanese Canadians in British Columbia, 1892-1949. S.T.M. Thesis. Vancouver, Union College, 1965.

\section{REGIONAL HISTORY}

A. Diocese, Congregation. Synod

Acadia. Brault, Pierre, L'Acadie et son église. Saint-Iean-sur-Richelieu, Éd. Mille Roches, 1977. Pp. 95.

Alberta. See : 5B. Buddhist - Kawamura.

Amos, Qué. Ebacher, Roger, La religieuse animatrice de paroisse : informations et réflexions sur l'expérience du diocèse d'Amos. Coll. L'Église du Québec, 5. Montréal : Fides, 1978. Pp. 85.

Antigonish, N.S. Maclean, Raymond A., ed., History of Antigonish. 2 vols. Antigonish : Formac, 1976. Pp. 163, 208.

Arctic. Hochbaum, H. Albert, "Arctic Steeples", The Beaver, 308,3 (1978) 28-35. (Anglican and Roman Catholic Missions).

British Columbia. See : 5B. Mennonite - Janzen ; United Church - Harrison ; United Church - Mitsui ; 10. Veillette ; Lamirande.

Bruce County, Ont. See : 11E. Carter.

Cape Breton. MacKinnon, Archibald, The History of the Presbyterian Church in Cape Breton. Antigonish, N.S. : Formac, 1975. Pp. 193.

Chicoutimi, Qué. See : 7. Lapointe.

Bélanger, Léonidas, "Les évêques de Chicoutimi", Saguenayensia, 20, 3-4 (1978) 88-93.

“Documents”, (du diocèse, 1878-1978), Saguenayensia, 20, $3-4$ (1978) 94-104.

Gagnon-Arguin, Louise, "Un siècle de vie religieuse au diocèse de Chicoutimi”, Saguenayensia, 20, $3-4$ (1978) 54-58. 
JEAN, Sr. Marguerite, s.c.i.m., "Fondation au diocèse de Chicoutimi de trois communautés religieuses de femmes", Saguenayensia, 20, 3-4 (1978) $59-63$.

Compton County, Qué. "The Parish and French Canadian Migrants to Compton County, Quebec, 1851-1891", Histoire sociale - Social History, XI, 21 (May, 1978) 134-143.

Eastern Townships, Qué. Smith, Françoise, The Establishment of Religion in the Eastern Townships, 1799-1851. M.A. Thesis. McGill U., 1977.

Fort William - Port Arthur, Ont. MacDonald, Marvin, The Reaction of Methodist and Presbyterian Churches in Fort William and Port Arthur Toward Immigrants from Continental Europe, 1903-1914. M.A. Thesis. Lakehead U., 1977.

Laguerre, Qué. Rogers, G.A., "Records of the Kirk Session of Laguerre", Journal annuel de la Société historique de la vallée de la Châteauguay, 5 (1972) 4-13.

London, Ont. Moore, Sr. Julia, s.c.j., "The Sisters of St. Joseph. Beginnings in London Diocese, 1868-1878", Study Sessions, 45 (1978) 37-56.

Longueuil, Qué. Lebrun-LaPierre, Odette, "Les Sœurs Grises à Longueuil", Société d'histoire de Longueuil - Bulletin, 9 (1976) 23-31.

Montréal. See : 3. Fournier; 8B. Glandelet.

Muenster, Sask. See : 11B. White.

New Brunswick. See : 10. Thériault.

Wynn, Graeme, "New Brunswick Parish Boundaries in the Pre-1861 Census Years", Acadiensis, 6,2 (1977) 95-105.

Newfoundland. See : 11D. Williams.

North Cumberland, N.S. Brown, Harry R., Churches and Clergy of North Cumberland. Pugwash, N.S. : North Cumberland Historical Society, 1975. Pp. 192, illus. ports.

Nouvelle-France. See : 3. Bédard ; 7. Baillargeon ; 11C. Campeau ; 11D. Campeau.

Chiche-St-Amant, Marie Aimée, La confrérie de la Sainte-Famille, 1663-1763. Thèse M.A., U. Laval, 1977.

Dubé, Jean-Claude, "Les intendants de la Nouvelle-France et la religion", Sessions d'étude, 45 (1978) 5-18.

Nova Scotia. See : 11D. Baum - "Social Catholicism ..."

Wallace, Arthur W., An Album of Drawings of Early Buildings in Nova Scotia. Heritage Trust of Nova Scotia and the Nova Scotia Museum, 1977. (Special section dealing with churches).

Ontario. See : 5B. Congregationalism - Kenyon ; 11A. Kenyon ; 11E. Crysdale ; Hemmerick. 
Fahey, Curtis, "The Development of Religion in Ontario in the Nineteenth Century", in: Harold Kalman, The Conservation of Ontario Churches. Toronto: Ministry of Culture and Recreation, 1977. Pp. 33-68.

Kalman, Harold D., The Conservation of Ontario Churches : A Programme for Funding Religious Properties of Architectural and Historical Significance. Toronto: Ministry of Culture and Recreation, 1977. Pp. vi, 130.

Québec. See : 3. Harris.

BÉDARD, Hélène, Maisons et églises du Quéhec. Coll. Civilisation du Québec no. 1, Ministère des Affaires culturelles, 1972. Pp. 50.

LEFÈBre, Jean-Jacques, "Monographies paroissiales", Québec Histoire, 2,2 (hiver, 1973 ) 72-74.

Québec, Qué. See : 1. Doyle.

Russeltown, Qué. Rogers, G.A., "Russeltown Church, 1826-1976", Journal annuel de la Société historique de la vallée de la Châteauguay, 9 (1976) 1-4.

Saguenay, Qué. See : 1. Côté.

Pouyez, Christian et Michel Bergeron, "L'étude des migrations au Saguenay (1842-1931) : problèmes de méthode", Histoire sociale - Social History, XI, 21 (1978) 26-61.

Saskatchewan. See : 11C. Ludwig ; 5B. Rome, Churches ..., Ukrainian-Baran.

Toronto, Ont. Masters, D.C., "The Anglican Evangelicals in Toronto, 18701900", Journal of the Canadian Church Historical Society, 20, 3-4 (1978) 51-65.

Trois-Rivières. VoIsine, Nive, "Un diocèse divisé contre lui-même, TroisRivières (1852-1885)", RUO, 47, 1-2 (1977) 226-236.

\section{B. Parish History}

(NOTE: Where information regarding author, place of publication, publisher, date of publication or pagination is not supplied in the entry, it is either because the information is not given, or because the work was commissioned and published by the institution itself.)

Almonte, Ont. McNeILl, James, Old St. Mary's: A Short Biography of the Church of the Holy Name of Mary, Almonte, Ontario. 1969.

Antigonish, N.S. Maclean, Raymond A., History of Antigonish. Vol. I. Pp. 163 ; Vol. II. Pp. 208. Antigonish : Formac, 1976.

Arva, Ont. Jared, Eleanor C., A Short History of the Life and Times of the Anglican Church in Arva, London Township, Ontario. (St. John the Divine). 1975 .

Ashfield, Ont. A History of North-East A shfield. Trinity United Church Women, Comp. Mildmay, Ont. : Town \& Country Crier, 1976. Pp. 322, illus., map. 
Bellechasse, Qué. Goulet, I.-Napoléon, comp., Mariages et nécrologie de Armagh, 1857-1973, co. Bellechasse et St-Gabriel de la Durantaie, 19101973, co. Bellechasse. Montréal : Éditions Bergeron, 1975. Pp. 109.

Mariages et nécrologie de la paroisse St-Charles, co. Bellechasse, 1749-1974. Montréal : Éditions Bergeron, 1975. Pp. 178,23,82.

Boucherville, Qué. Moreau, Jean-Paul, Sainte-Famille de Boucherville. Boucherville: Société d'histoire des Îles Percées, 1977. Pp. 32.

Brookfield, N.S. LindSAy, Arthur J., Knox Church : A History, 1976. Pp. viii, 206.

Buckingham, Qué. See : 2. Houle, "Mariages..."

Burlington, Ont. ANDerson, William A., A Historical Sketch of Appleby United Church. 1974.

Calgary. Dougl.As, Jessie, ed.. Grace Presbyterian Church, Calgary, Alta. 1973. Pp. 29.

Caraquet, N.B. See : 7. Centenaire ...

Carleton Place, Ont. Langtry, D. Ralph, Fourscore and Ten, 1882-1972. 1972. (St. James Church).

Charlottetown, P.E.I. The Central Christian Church : Its Origins and Growth. 1975. Pp. 24.

Châteauguay, Qué. Laberge, André, Saint-Joachim de Châteauguay, 17751975. Pp. 75.

Chatham, Ont. Blackwell, Norman T. and Lorna, History of the Church of the Holy Trinity, Chatham, Ontario, 1875-1975. 1974.

Chicoutimi, Qué. See : 2. Bélanger ; 8. Conroy.

Chipman Corner, N.S. "Two Early Churches at Chipman Corner, N.S. : The Acadian Church of Saint Joseph, 1689-1755; The Congregational Church of Horton, Cornwallis 1768-1874", 1975. Pp. 4.

Cooksville, Ont. Stevenson, Ellen, A History of Cooksville United Church. Cheltenham, Ont.: Boston Mills Press, 1975. Pp. 48, ill.

Corner Brook, Nfld. The Salvation Army, Corner Brook Temple Corps. From Victory Unto Victory : Corner Brook Temple Corps Golden Jubilee, 1924-1974. St. John's, Nfld., 1974 Pp. 129.

The Salvation Army, Corner Brook Citadel Corps, Fifty Years of Service, 1924-1974. Whitby, Ont. : Canada Yearbook Services Ltd., 1974. Pp. 72.

Cornwall, P.E.I. A History of Cornwall Church. United Church, 1975. Pp. 54.

Cornwallis, Ont. Eaton, E.L., "Fifty Years of Church Union in Cornwallis", 1975. Pp. 3.

Cornwallis Township, N.S. Eaton, E.L., "The Forgotten Christians of Cornwallis Township", Nova Scotia Historical Quarterly, 7-1 (March, 1977) 41-54. 
Cowichan Station, B.C. Pop pleton, T., "St. Andrew's Anglican Church Cemetery, Cowichan Station, B.C.", British Columbia Genealogist, 4,4 (1975) 4-7.

Dartmouth, N.S. KerR, Margaret, comp., Church of St. James, Dartmouth, N.S., 1871-1971. 1971. Pp. 44.

Edmonton, Alta. Monckton, Jean A., All Saints' Anglican Cathedral. 1975. Pp. 104.

The Pioneers: McDougall Church, Our First 100 Years, 1871-1971. 1971. Pp. 32.

Gatineau, Qué. Bourgoin, L.-M., "La chapelle des chantiers (1846-1868)", Asticou, 20 (déc.. 1978) 70-73.

Grafton, Ont. Millman, Thomas R., The Story of St. George's Church, Grafton. (Anglican). Brighton: Self's Print Service, 1974.

Grenfell, Sask. Homecoming '71 and St. Peter and St. Paul Jubilee, Grenfell, Sask. Montmartre, Sask. : Icon Press, 1971 ? Pp. 21.

Halifax, N.S. PerRy, Margaret L., "The Founding of St. Mathew's", (United Church), Atlantic Advocate, 65 (1974) 29-30.

Hamilton, Ont. "Baptismal Records of the Church of the Ascension (Anglican) Hamilton, 1851-53", Wentworth Bygones, 11 (1975) 59-64, “1854-1855"Wentworth Bygones, 12 (1977) 49-54.

Campbell, Marjorie Freeman, A History of Beth Jacob Congregation, 18861969. Hamilton : 1969. Pp. 118.

Fletcher, J.T.L., “A History of St. Patrick's Roman Catholic Church”, Wentworth Bygones, 11 (1975) 49-53.

Hants-Harbour, Nfld. Rowe, Melvin, Wesleyan-Methodism in the HantsHarbour Circuit, 1824-1974. Pp. 28,1.

Hazeldean, Ont. Mills, Shirley, The History of Glen Cairn United Church. 1975.

Hébertvilie, Qué. SÉGuIN, Normand, Notre-Dame d'Hébertville, 1850-1900, une paroisse de colonisation au XIXe siècle. Thèse de Ph.D. U. d'Ottawa, 1976. Pp. ix, 356.

Hemmingford, Qué. L'Espérance, Aileen, "The Churches of Hemmingford", Journal annuel de la Société historique de la Vallée de la Châteauguay, 10 (1977) 20.

Huntingdon, Qué. "Schools and Churches of Huntingdon", Journal annuel de la Société historique de la Vallée de la Châteauguay, 8 (1975) 35-42.

L'Islet, Qué. Fortin, Guy, "Les presbytériens et les protestants du comté de L'Islet", L'Ancêtre, 2,9 (1976) 413-419.

Kars, Ont. Curtis, P.B. et al., Elmview Cemetery, Kars, Ontario. North Gower Township, Lot 24, Conc. 1. Ottawa: Ottawa Branch, Ontario Genealogical Society, 1974. 
Kelly's Cross, P.E.I. A History of Kelly's Cross Parish. 1974. Pp. 162.

Lafontaine, Ont. See : 2. Houle - "Répertoire ..."

Lamèque, N.B. LeBreton, Clarence, "Notes historiques sur la cloche de l'église de Lamèque, N.B.", La Société historique Nicolas-Denys, Revue d'Histoire, 3 (1975) 8-9.

Laprairie, Qué. See : 2. Jetté.

Leeds County, Ont. Hughes, Alice, Leeds County Cemeteries : Blanchard's. Campbell's, Jelly's, R.C. by the Pond. Ottawa: Ottawa Branch, Ontario Genealogical Society, 1972.

Lethbridge, Alta. In His Service: St. Augustine's, Lethbridge, 1886-1976. (Anglican). 1976. Pp. xiii, 86.

Lévis, Qué. Ouellet, Alphonse, Saint-David-de-l'Auberivière (comté de Lévis): centenaire, 1876-1976. Pp. X, 220.

Longueuil, Qué. Lebrun-LaPierre, Odette, "La troisième église St-Antoine de Padoue construite en 1885", Société d'histoire de Longucuil - Bulletin, 9 (1976) 3-22.

Madawaska, N.B. See : 7. La Madawaska.

Maillardville, B.C. See : 9. Layton.

Maryhill, Ont. See : 11A. Schenk.

Mansonville, Qué. BaILey, Mary F., History of Mansonville Methodist Church, 1873-1925, Mansonville United Church, 1925-1973 : and the History of Methodism in the Area to 1873. 1974. Pp. 77.

Martintown, Ont. Grant, Rhodes C.M., A Story of St. Andrew's Preshyterian Church, Martintown. 1975.

Maskinongé, Qué. Plante, Clément, comp.. Mariages de la paroisse de StJustin, co. Maskinongé, 1858-197I. Montréal : Éditions Bergeron, 1975. Pp. xvii, 86.

McDonalds Corners, Ont. GedDes, H., comp., Historical Sketch of McDonalds Corners, Snow Road and Elphin. (Ont.) (Preshyterian Church Centennial, 1875-1975). 1975 ? Pp. III, 62.

Medicine Hat, Alta. St. Barnabas Church of Medicine Hat, Alberta : Ninetieth Anniversary, 1884-1974. 1974. Pp. 48.

Mill Bay, B.C. Poppleton, Dorothy M. and Thomas C. Poppleton, "Mill Bay United Church, Island Highway, Mill Bay, B.C.”, British Columbia Genealogist, 4,1 (1975) 15-18.

Mistassini, Qué. Perron, Normand, "L'action des Trappistes dans la région de Mistassini, 1892-1927", Saguenayensia, 19,4 (1977) 91-95.

Moncton, N.B. Pincombe, Alex and Rhoda, The Free Mceting House: A History of Moncton's Oldest Building. 1966. Pp. 30. 
Montebello, Qué. The Papineau Chapel. Ottawa: Heritage Canada, 1975. Pp. 8.

Montréal, Qué. Benyak, Irma and Aladár Komjáthy, eds., Magyar Református Egyházi Hungarian United Church, Montreal, Quebec. 1976. Pp. 102.

Roy. Raoul, Les églises vont-elles disparaître? - Dossier de la lutte pour sauver de la démolition l'église, la chapelle et le presbytère de la paroisse Sainte-Catherine-d'Alexandrie à Montréal. Montréal : Les Éditions du Franc-Canada, 1976.

Rousseau, Louis, La prédication à Montréal de 1800 à 1830: approche religiologique. Coll. "Héritage et projet". no. 16. Montréal: Fides. 1976. Pp. 269.

Moosonee, Ont. Peterson, Olive Mackay, The Land of Moosonek. Schumacher. Ont. : Diocese of Moosonee, 1974.

Morganston, Ont. Platt, Winnifred, From Horses to Mopeds : Morganston. 1830-1975. (United Church). 1975. Pp. 31.

Newcastle, N.B. Mаскау, Margaret. St. James Presbyterian Church, 18251975. 1976. Pp. 63.

New Dublin, Ont. History of the Anglican Church at New Dublin in the Parish of Elizabethtown in the Province of Ontario. 1955. Pp. 23.

Niagara-on-the-Lake, Ont. Sim, Helen T., History of St. Vincent de Paul Parish, Niagara-on-the-Lake, 1835-1973. 1973.

Normandin, Qué. St-Hilaire, Marc, "Normandin, un modèle de paroisse agricole", Saguenayensia, 20,2 (1978) 48-51.

North Cumberland, N.S. Brown, Harry R., Churches and Clergy of North Cumberland. Pugwash, N.S. : North Cumberland Historical Society, 1975. Pp. 192.

Nouvelle-France. See : 9. Hurtubise.

Ottawa, Ont. The First Century. Ottawa : Erskine Presbyterian Church. 1974.

Kept by His Power : The Evangelical Lutheran Church of St. Paul, Wisconsin Synod, Ottawa, Ontario, 1874-1974. 1974.

LitTle, Charles H., All Saints' Church (Sandy Hill) : A Short History. Ottawa: Love Print Service, 1975.

Peel County, Ont. See : 2. Britnell.

Penetanguishene, Ont. See : 2. Houle, "Répertoire..."

Perkinsfield, Ont. See : 2. Houle, "Répertoire ..."

Perth, Ont. Wilson, Gordon Weir and George Mclean Richardson, $A$ History of St. Paul's United Church and its Antecedents in Perth, 1817. 1975. 1975.

Peterborough, Ont. Jones, Elwood H., St. John's, Peterborough : The Sesquicentenial History of an Anglican Parish. 1976. Pp. 110. 
Petrolia, Ont. Turner, Rob., The Churches of Petrolia: A Calendar for 1975. London, Ont., 1975.

Pointe du Chêne, N.B. Belliveau, John Edward, A History of the Roman Catholic Church at Pointe du Chêne, New'Brunswick and the Parish of Our Lady of Mercy (1954-1974). 1974. Pp. 19.

Port Kells, B.C. "St. Oswald's Anglican Church Cemetery, Port Kells, B.C.", British Columbia Genealogist, 4,3 (1975) 23-26.

Québec, Qué. See : 7. Fleurent: Gauthier ; Raymonde.

Provost, Honorius, Abbé. Notre-Dame-de-la-Garde de Québec (1877-1977). Société historique de Québec. Cahiers d'Histoire, no. 30. Québec : s.n.. 1977. Pp. 277.

Ranfurly, Alta. Erickson, George, comp.. History of the Ranfurly United Church and Its Congregation. 1975. Pp. 16.

Red River, Man. Pannekoek, Frits, "The Anglican Church and the Disintegration of Red River Society, 1818-1870", in: Carl BERGER and Ramsay Cook, eds., The West and the Nation, Toronto: McClelland and Stewart Ltd., 1976. Pp. 72-90.

Regina, Sask. Spilnym zusylliam i napolhlyıoiu pratseiu. (Conviction-dedication-effort). St. Basil the Great Parish, Regina. Sask. (Ukrainian Catholic). 1975. Pp. 302.

Reinland. ZaCharias. Peter D., Rcinland : An Experience in Community. 1976. Pp. 350.

Rexdale, Ont. Hamilton, Hazel, comp., The Story of Rexdale United Church: As Written by all Who Have Shared in This Work of the Lord. 1975.

Richmond, Ont. Armstrong, Edna, et al.. St. Paul's United Church Cemetery (the old Methodist Cemetery) Richmond. Ontario: part 1 \& 2 (King's Park), Richmond Village part lot 26N1\%2 Conc. III, Goulbourn Township. Ottawa : Ontario Genealogical Society, 1974.

Neville, George A., St. Andrew's Presbyterian Church Cemetery, Richmond, Ontario. Ottawa : Ontario Genealogical Society, 1975.

Richmond, Qué. Richmond and Melbourne United Church. 1974. Pp. 58.

Rigaud, Qué. Prud'homme, François, Notre-Dame de Lourdes de Rigaud: cent ans de dévotion mariale, 1874-1974. 1974. Pp. xi. 224.

Rimouski, Qué. Centenaire de la paroisse de Notre-Dame du Sacré-Caur, Rimouski, 1875-1975. 1976. Pp. 223.

Rıou, Grégoire, "La généalogie dans les prônes de St-Fabien de Rimouski". L'Ancêtre, 2,8 (1976) 385-388.

Saguenay, Qué. "Une église centenaire”. Sagucnayensia, 17,6 (1975) 140.

St. Agatha, Ont. Schumilas, Mrs. Anthony, "The Shrine of the Sorrowful Mother at St. Agatha”, Waterloo Historical Society, 63 (1975) 11-12. 
St. Andrews, N.B. Cockburn, Melville N. and Maccoubrey, E. Willa, $A$ History of Greenock Church, St. Andrew's, New Brunswick, 1821-1974. 1974. Pp. 84.

Sainte-Anne-de-Beaupré, Qué. See : 2. Racine.

Lefèbre, Eugène, Guide-Book for Pilgrims and Visitors of Ste. Anne. Québec : Basilica of Ste. Anne, 1973. Pp. 112.

Gagnon, Gabriel-U., "Églises d'hier et d'aujourd'hui", 1976. Pp. 39.

Proulx, Laurent, "Les voûtes secondaires de la Basilique Sainte-Anne". 1976. Pp. 41.

Sainte-Anne-de-Beaupré : Its Basilica, Its Other Holy Places. Saint Anne's Basilica, 1975. Pp. 120.

Sainte-Anne du Petit Cap, Qué. Laliberté, François, "Liste des marguilliers de la paroisse Sainte-Anne du Petit-Cap", L'Ancêtre, 3,7 (1975) 305-308.

Sainte-Anne-de-Sorel, Qué. White, Walter Syndey, Le cheval du Moine : une histoire illustrée à l'occasion du centenaire de la paroisse et de la municipalité de Sainte-Anne-de-Sorel, 1876-1976. (Municipalité de SteAnne-de-Sorel, 1976). Pp. 236.

Saint-Anselme, Qué. ArSenault, Anselme, Ton histoire est une épopée : la paroisse St-Anselme. 1976. Pp. 315.

Saint-Antoine-sur-le-Richelieu, Qué. Album-souvenir, 225e anniversaire de la paroisse St-Antoine-de-Padoue, 1750-1975. 1975. Pp. 264.

Sainte-Foy, Qué. See : 2. Scallen.

Saint-Gabriel-de-Brandon, Qué. Bergeron, Henri et al., St-Gabriel, notre perle. 1975. Pp. 215.

Saint-Georges de Beauce, Qué. See : 7. Tran-Khanh.

Saint-Jean-Port-Joli, Qué. Saint-Pierre, Angéline, L'église de Saint-JeanPort-Joli. Québec: Garneau, 1977. Pp. 217.

Saint-Jean-de-Québec. See : 1. Signori-Laforest.

St. John's, Nfld. The Dissenting Church of Christ at St. John's, 1775-1975. (St. David's Presbyterian Church). 1976. Pp. 230.

Rowe, C. Francis, A Record of the 275th Anniversary of the Cathedral Parish of Saint John the Baptist, St. John's, Newfoundland, 1699-1974. 1975. Pp. 73.

Story, George M., George Street Church, 1873-1973. 1973. Pp. x, 86.

Sainte-Lucie-des-Laurentides, Qué. Brisson, Gilles, Histoire de Ste-Lucie-desLaurentides: en bref. (Ste-Lucie des Laurentides), G. Brisson, 1974. Pp. 140.

Sainte-Marie-des-Hurons, Ont. Peletier, Jacques, "La mission Sainte-Mariedes-Hurons", Asticou, 17, (av., 1977) 19-28. 
St. Mary's Bay, N.S. See : 2. Smith.

Saint-Moïse, Qué. Lavore, Charles, Mme, Centenaire de Saint-Moïse, 18731973. 1973. Pp. 100.

Sainte-Thècle, Qué. See : 2. Béland.

Sarnia, Ont. DubeK, Victor J., Our Lady of Mercy : A Centennial History, 1878-1978. 1978. Pp. 56.

Sault, Qué. Glen, Marie-Andrée, "Les trois paroisses du Sault", Racar, 4,1 (1977) 29-31.

Sault-au-Récollet, Qué. Beaudoin, Marthe, "La visitation du Sault-au-Récollet - La plus ancienne église de l'île de Montréal", 1977. Pp. 12.

Scotsburn, N.S. Our Heritage of Faith, 1822-1975. (Bethel Presbyterian). 1975 ? Pp. 12.

Sharon, Ont. Adamson, Anthony, "The Ark of the Children of Peace", York Pioneer, 72,1 (1977) 28-30.

Mann, Carolyn, "Legends and Folktales of Sharon", York Pioneer, 73,1 (1978) $11-17 ; 73,2$ (1978) $23-28 ; 74,1$ (1979) 5-9.

Shellburne, Ont. Barr, Grace, et al., A Place to Pray: The Story of Primrose United Church. 1975.

Sherbrooke, Qué. Gravel, Albert et Raymond LaMbert, Horizons anciens : en marge du centenaire de l'archidiocèse de Sherbrooke. 1974.

Shillington, Ont. Gordon, Elizabeth M. and George A. Neville, Old Methodist (Shillington) Cemetery : A Pioneer Cemetery of Carleton County, and Pictorial History. Ottawa : Ottawa Branch, Ontario Genealogical Society, 1974.

Shippegan, Qué. De Grâce, Éloi, "L'église United Church de Shippegan", La Société historique Nicolas-Denys, Revue d'histoire, 5 (janvier-mars, 1977) 4-10.

Springhill, N.S. Campbell, Bertha J., "Early History of Presbyterian of Springhill, Nova Scotia", Nova Scotia Historical Quarterly, 7,1 (1977) $1-30$.

-. "Early History of St. Andrew's-Wesley United Church of Canada, Springhill, Nova Scotia", Nova Scotia Historical Quarterly, 6,2 (June, 1976) 173-192.

Sudbury, Ont. SzILva, Ted, ed., Church of Christ the King: 60th Jubilee, 1917-1977. Sudbury : Journal Printing, 1977.

Sunbory County, N.B. See : 2. Hayward.

Sussex, N.B. A History of Trinity Anglican Church and its Rectors, 1792 1974. 1974. Pp. 38.

Sweetsburg, Qué. Moore, Ruby G., “Christ Church - Sweetsburg, 1974”, Missisquoi County Historical Society, Report, 13 (1974) 12-14. 
Thornhill, Ont. Peacock, Egerton, Thornhill United Church : A History of the Methodist, Presbyterian and United Church from 1803 to 1975. 1975.

Thunder Bay, Ont. Judd, Esther L., Heritage of One Hundred Years, 1873 1973 : St. Paul's United Church, Thunder Bay, Ontario. 1973.

St. Andrew's Catholic Church Centennial, 1875-1975: Under the Direction of the Jesuit Fathers. 1975.

Torbay, Nfld. Hayes, Gerald, comp., Si. Nicholas Anglican Church, Torbay, 50th Anniversary, 1924-1974; One Hundred and Fifty Year History of the Congregation, 1819-1974. 1974. Pp. 30.

Toronto, Ont. See : 8. Carroll.

Gentles, Ian, St. Bartholomew's Church, 1873-1973: A History. 1973. Pp. 19.

50 ér/Years : Szent Ersébet Egyházkozseq, St. Elizabeth of Hungary Church, Toronto. 1978. Pp. 40.

McFall, A. David, John I. Rempel and Jean McFall, "St. Paul's Presbyterian Church and Cemetery", York Pioneer, 71,2 (1976) 27-36.

PIKE, Myrtle, comp., The Story of St. Paul's Long Branch, 1924-1975. 1975.

Tracadie. La Plante, Corinne, r.h.s.j., "Petit historique de l'œuvre des Hospitalières de Saint-Joseph à Tracadie", La Société historique Nicolas-Denys, Revue d'Histoire, 2,3 (1974) 4-11.

Truro, N.S. Dunphy, Clifford R., St. John's Church, Truro, Nova Scotia. Centennial, 1973. Pp. 38.

Twillingate, Nfld. See : 7. Association.

Vancouver, B.C. Jamieson, R.D., ed., Retrospect : The Story of St. Philip's Anglican Church, Vancouver, 1925-1975. 1975. Pp. 143.

Shevchuk, Sevastiian, Duadtsiat richchia ottsiv Vassylii an u Vankuveri, B.K. (20th Anniversary of the Basilians in Vancouver, B.C.). (Sevastiian Shevchuk). (Vankuver : oo. Vasyliiany, 1957).

Vanier, Ont. See : 2. Houle, "Mariages de Saint-Charles..."

Wakaw, Sask. Becker, A., "The Lake Geneva Mission, Wakaw, Saskatchewan", Saskatchewan History, 29,2 (1976) 51-64.

Waterdown, Ont. See : 8B. Noble.

Wellington, P.E.I. Immaculate Conception Parish Centennial. 1975. Pp. 69.

Westport, N.S. Green Head (pseud.), Throw Out the Life-Line Across the Dark Wave : Westport Baptist Church, Briar Island, Nova Scotia; Hymnal History from 1809. 1976. Pp. 20.

Westport, Ont. Jackman, Edward, O.P., Saint Edward's Parish History. 1978.

Weyburn, Sask. Eaglesham, Isobel, comp., Pardon me Madame President! 75 Years in Knox Presbyterian Church, Weyburn: Centennial Issue. 1975. Pp. 48. 
Winnipeg, Man. See : 5B. Jewish-Ludwig ; Mennonite-Driedger.

Bredin, Thomas F., The Cathedral Story : A Brief History of St. John's Cathedral, Winnipeg, in Commemoration of its 50th Anniversary, 19261976. Winnipeg: Peguis Publishers, 1975. Pp. 13.

Schmidt, Anita E., On the Banks of the Assiniboine : A History of the Parish of St. James. Winnipeg : L.F. Schmidt, 1975. Pp. iii, 135, ill.

SCHubert, Chris, "Brief History of Scandinavian Choirs in Winnipeg", Icelandic Canadian, 33,3 (1976) 11.

Wolfe Island, Ont. Small, Fern., St. Lawrence United Church Cemetery, Concession XVIII, Lot 9, Wolfe Island, Ontario, map reference 009955. Ottawa : Ontario Genealogical Society, 1972.

Wolverine, Sask. 50th Anniversary of the Parish of Wolverine, Saskatchewan. (Ukrainian Catholic). 1962. Pp. 49.

Woodland Beach, Ont. Train, Gladys, 50th Anniversary, Community Church, 1976. Pp. 20.

Wyoming, Ont. St. Andrew's Presbyterian Church in Canada, St. Andrew's, Wyoming, Presents a History of the Congregation for One Hundred Years, 1866-1966. 1966. Pp. 44.

\section{INSTITUTIONS}

See : 1. Provost ; 2. Matériaux...; Records of the Protestant Children's...

Baillargeon, Noël. Le Séminaire de Québec de 1685 à 1760. Québec : Les Presses de l'U. Laval, 1977. Pp. XIV, 459.

BoIsClaIR, Marie-Nicole. Hôtel-Dieu de Québec/Catalogue des peintures. Dossier 24, Ministère des Affaires culturelles, 1977. Pp. 195.

Boudreau, Ephrem. "Le petit Clairveaux (1825-1919)", La Société historique acadienne - Les Cahiers, 7,3 (1976) 131-146. (Trappistes à Tracadie, N.-E.).

Casaubon, Louis. Quelques notes pour l'histoire intime du Collège. Éd. par Réjean Olivier. L'Assomption, Bibliothèque du Collège de l'Assomption, 1976. Pp. 67.

DesJaRdins, Jeanne. "Le couvent de Douglastown : 77 ans de service", Revue d'histoire et de traditions populaires de la Gaspésie, 57 (janv.-mars, 1977) 7-22.

DE VALK, Alphonse. "Independent University or Federated College? The Debate Among Roman Catholics During the Years 1918-1921". Saskatcheran History, 30,1 (1977) 18-32. (St. Thomas More College).

Edinborough, Arnold, ed. The Enduring Word: A Centennial History of Wycliffe College. Toronto and Buffalo: University of Toronto Press, 1978. Pp. 136. 
Fleurent, Maurice. L'éducation morale au Petit Séminaire de Québec 1668-1857. Thèse de D. ès L. U. Laval, 1977. Pp. XXX - 504.

GAUTHIER, Raymonde. L'architecture civile et conventuelle à Québec (16801726). Thèse de M.A. U. Laval, 1976. Pp. xvii, 193.

-. "Les constructions de l'Hôtel-Dieu (1637-1960) - IIIe partie : le rétablissement (1800-1886)", Conseil des monuments et sites du Québec Bulletin, 5 (nov.-déc., 1977) 43-51.

Gauthier, Armand. "Le couvent des Récollets à Montréal", Mémoires de la Société généalogique canadienne-française, 28,4 (1977) 270-273.

Genest, Jean-Guy. "L'École de génie de Chicoutimi", Saguenayensia, 19,4 (1977) 96-98. (CEuvre des Maristes, 1948-1969).

Giroux, Alice. Histoire du Collège Basile-Moreau, 1933-1968. Montréal : Sœurs de Sainte-Croix, 1976. Pp. viii, 268.

Grand'MaIson, Georgette. Les élèves du collège-séminaire de Rimouski, 18631903. Thèse M.A., U. d'Ottawa, 1972.

Lamontagne, Maurice. "La faculté des sciences sociales de Laval : prélude de la révolution tranquille", Histoire sociale/Social History, 19 (mai, 1977) 146-151.

Lapornte, Mgr Eugène. "Le Séminaire de Chicoutimi", Saguenayensia, 20, 3-4 (1978) 86-87.

Mallon, James Francis, c.s.b. Fifty Years Later: A History of the Class of 1929, St. Michaels College in the University of Toronto, Written in its Jubilee Year. Toronto : U. of St. Michael's College, 1979. Pp. 24.

Neatby, Hilda, Frederick W. Gibson and Roger Graham, ed. Queen's University: Vol. 1, 1841-1917: And Not to Yield. Montreal : McGill-Queen's U. Press, 1979. Pp. 368.

Owens, Joseph. The Philosophical Tradition of St. Michael's College, Toronto. Toronto : U. of St. Michael's College Archives, 1979. Pp. 40.

Rothwell, Alfred. Love and Good Sense: The First Half-Century of the Salvation Army Grace Hospital, Calgary, 1926-1976. Pp. 79.

Rousseau, François. "Hôpital et société en Nouvelle-France : l'Hôtel-Dieu de Québec à la fin du XVIIe siècle", RHAF, 31,1 (juin, 1977) 29-48.

Sisters of St. Elizabeth of the Third Order of St. Francis of Assisi. Commemorating Fifty Years of Service of the Sisters of St. Elizabeth at St. Michael's Hospital, Cudworth, Saskatchewan, 1926-1976. Battleford, Sask. : Marian Press, 1976. Pp. 56.

Swain, Valorie E. "The Bishop's House Saved", Historic Kingston, 27 (Jan., 1979) 2-4.

Tunney, Evelyn, Comp. Sisters of Service, Edson, Alberta, 1926-1976: 50 Years of Service, St. John's Hospital. Pp. 28. 
Vigod, B.L. "Ideology and Institutions in Quebec. The Public Charities Controversy ,1921-26", Histoire sociale/Social History, XI, 21 (May, 1978) 167-182.

Villiard-Bériault, Denise. Saint-Laurent : Un collège se raconte : 120 ans de collège, 10 ans de cégep. Montréal : Fides, 1977. Pp. 158.

Vorsine, Nive. "Il y a cent ans ... une bénédiction ... difficile", Revue d'histoire du Bas Saint-Laurent, 3,1 (1976) 12-16. (Petit Séminaire de Rimouski en 1875).

\section{INDIVIDUAL BIOGRAPHY AND BIOGRAPHICAL MATERIAL}

\section{A. General}

See : 1. Mallea ; 5B. Rome, Churches... - Latin - Gingras ; 7. Mallon.

\section{B. Individuals}

Aberhart, William. Ellote, David R. "Antithetical Elements in William Aberhart's Theology and Political Ideology", $C H R, 59,1$ (March, 1978) 38-58.

Bailey, Jacob. Siegenthaler, David. "Nova Scotia, 1784 : A Letter of Jacob Bailey", Journal of the Canadian Church Historical Society, 19, 3-4 (1977) 131-137.

Bégin, Mgr Louis-Nazaire (1840-1925). See : 6A. Chicoutimi-Bélanger.

Bethune, Norman.

Slater, Peter. "Religion as Story: The Biography of Norman Bethune", in: Religion and Culture in Canada. Waterloo: Wilfrid Laurier U. Press, 1977. Pp. 289-314.

StEWART, Roderick. The Mind of Norman Bethune. Toronto : Fitzhenry and Whiteside, 1977. Pp. 150.

Beynon, Francis Marion. Cook, Ramsay. "Francis Marion Beynon and the Crisis of Christian Reformism", in: Carl BERGER and Ramsay Cook, eds., The West and the Nation, Toronto: McClelland and Stewart, 1976. Pp. 187-208.

Bickersteth, J. Burgon. Bickersteth, J. Burgon. The Land of Open Doors. Toronto: U. of Toronto Press, 1977. Pp. 268. (Account of lay Anglican missionary).

\section{Bourassa, Henri.}

LEvITT, Joseph. "Images of Bourassa", JCS/REC, 13,1 (1978) 100-113.

Henri Bourassa - Catholic Critic. Ottawa : Canadian Historical Association Booklets, 29, 1976. Pp. 22. 
Bourgeoys, Marguerite. Cimichella, André-Marie. "Marguerite Bourgeoys : lumière sur notre ville”. Montréal : Éditions Jésus-Marie et notre temps, 1974. Pp. 71.

\section{Bourget, Mgr Ignace.}

Cimichella, André-Marie. "M Montréal : Éditions Jésus Marie et notre temps, 1976. Pp. 32.

LARIvière, Florian. "Mrrr Bourget et l'université". Relations, 424 (mars, 1977) 78-9.

Bowen, Rev. J.C. See : 2. Sermons, correspondence...

Briand, Mar Jean-Olivier. Brunet, Michel. "M"r Jean-Olivier Briand, homme d'État au service des Canadiens ou valet à la solde des autorités britanniques", Asticou, 16 (sept., 1976) 9-21.

Brûlé, Étienne. Kent, Donald H. "The Myth of Étienne Brûlé", Pennsylvania History, XLIII (Oct., 1976) 291-306.

Budd, Rev. Henry. Pettipas, Katherin Ann. A History of the Work of the Reverend Henry Budd Conducted Under the Auspices of the Church Missionary Socicty. 1840-1875. M.A. Thesis. U. of Manitoba, 1972.

Carroll, John. McKane, Pamela. "John Carroll and the Beginnings of Hope Tabernacle", York Pioneer, 74,1 (1979) 11-21.

Case, William. Phinney, William R. "William Case : Apostle to the Canadian Indians", The Canadian Methodist Historical Society, Papers, 1978. Pp. 40. (Available, U.C.C.A.).

Casson, François Dollier de. Leblant, Robert. "Correspondance inédite du sulpicien François Dollier de Casson, historien breton de Montréal en Canada". Paris: Bibliothèque nationale, 1977. Extrait des Actes du 97e congrès national des sociétés savantes, Nantes, 1972. Pp. 309-314.

Coady, Fr. M.M. See : 11B. Faris.

Conroy, Mar George. "Visite de Mrrr Conroy à Chicoutimi", Sagucnayensia. 19,3 (1977) 59-60.

Coster Scovil, G.C. See : 10. Coster Scovil.

Desjardins, Alphonse. Lamarche, Jacques. Alphonse Desjardins, un homme au service des autres. Montréal : Éditions du Jour, 1977. Pp. 173.

Doucet, Mar Stanislas-J. DeGrâce, Éloi. Biographie de M!r Stanislas-J. Doucet, p.d., 1847-1925. Thèse M.A. U. de Moncton, 1977.

Doull, Alexander John, Bishop. Esselmont, Harriett E.A. "Alexander John Doull: An Appreciation". Journal of the Canadian Church Historical Society, 18,4 (1976) 98-107.

Feild, Edward. Jones, Frederick. Edward Feild, Bishop of Newfoundland, 1844-1876. Newfoundland Historical Society, No. 4, 1976. 
Gallant, Arthur. Hubert, Adé. "Le père Arthur Gallant (1896-1976) Prêtre Eudiste", Cahiers d'histoire - Société d'histoire de la Côte nord, 4 (sept., 1977) 3-32.

Glandelet, Charles de. Glandelet, Charles de. Le vray esprit de l'Institut des sours séculières de la Congrégation de Notre-Dame établi à VilleMarie en l'Isle de Montréal en Canada: notes rédigées par l'abbé Charles de Glandelet, 1700-1701. Montréal : Congrégation de Notre-Dame, 1976. Pp. xxiv, 94.

\section{Groulx, Lionel.}

Filion, Maurice, directeur. Hommage à Lionel Groulx. Montréal : Leméac, 1978. Pp. 224.

Giguère, R.P. Georges-E., s.j. "Lionel Groulx. son mythe et ses mythes", Sessions d'étude, 45 (1978) 19-40.

LACRoIX, Benoît. "Lionel Groulx et ses croyances", Maurice Filion. éd., Hommage à Lionel Groulx. Montréal : Leméac, 1978. Pp. 95-118.

RICARD, François. "Lionel Groulx, Action française, État français". Voix et images du pays, 9 (Montréal : U. du Québec, 1975) 11-33.

Hawkins, Fr. Michael J. Loogman, P. Footsteps of a Giant : The Life Story of Father Michael J. Hawkins, s.j. Belleville: Mika Publishing. 1977. Pp. 324.

Hunter, James. "The Achievements and Frustrations of James Hunter", Journal of the Canadian Church Historical Society, 19, 3-4 (1977) 138-165.

Hurford, Grace Gibberd. See : 10. Hurford.

Jones, Rev. Peter. उмiтh, Donald B. "The Transatlantic Courtship of the Rev. Peter Jones", The Beaver, 308,1 (1977) 4-13: "Eliza and the Rev. Peter Jones", 308,2 (1977) 40-46; "Peter and Eliza Jones: Their Last Years", 308,3 (1977) 16-23.

Labrecque, Mgr Thomas (1849-1932). See : 6A. Chicoutimi-Bélanger.

Lamarche, Mgr Charles-Antonelli. See : 6A. Chicoutimi-Bélanger.

Langevin, Archbishop Adélard. See : 11B. Rusak.

\section{de Laval, Mgr François-Xavier.}

Cimichella, André-Marie. "François de Laval, Notre père dans la foi". Coll. Nos grandes figures, no. 6. Montréal : Éditions Jésus Marie et notre temps, 1974. Pp. 39.

Provost, Honorius. “Mr de Laval (1623-1708)”, Québec Histoire, 2,2 (hiver, 1973 ) 38-41.

Legal, Archbishop. See : 11B. Rusak.

Legault, Émile, c.s.c. "Le Père Legault se raconte", Asticou, 19 (avril, 1978) 12-22. 
Lynch, Archbishop John J. Stortz, Gerald J. "Archbishop Lynch and the Toronto Savings Bank", Study Sessions, 45 (1978) 5-20.

MacDonell, Bishop Alexander. ReA, James Edgar. Alexander Macdonell and the Politics of Upper Canada. Ph.D. Thesis, Queen's U., 1972.

Mailloux, Alexis. Langenier, Gilles. Vie et auvre d'Alexis Mailloux, membre du clergé du XIX ${ }^{r}$ siècle. Thèse M.A., U. d'Ottawa, 1971.

Mance, Jeanne.

Cimichella, André Marie. "Jeanne Mance retrouvée". Montréal : Publications Jésus Marie et notre temps, 1973. Pp. 25.

-. "Maisonneuve et Mance : Premiers parents de Montréal". Montréal : Éditions Jésus Marie et notre temps, 1974. Pp. 15.

Marie de l'Incarnation.

Boucher, Ghyslaine. Du Centre à la Croix: Marie de l'Incarnation 15991672: Symbolique spirituelle. Coll. Symbole et esprit. Montréal : Fides, 1977. Pp. 194.

MicheL, Robert. La voie de l'Esprit chez Marie de l'Incarnation. Thèse Ph.D., U. Saint-Paul, Ottawa, 1971.

Mathevet, Fr. DAY, Gordon M. The Mots Loups of Father Mathevet. Ottawa : National Museums of Canada, 1976. Pp. 430.

McClure, Rev. Robert. Scott, Munroe. McClure: The China Years of Dr. Bob McClure. Toronto: CANEC, 1977. Pp. x, 409.

McDonald, Rev. Donald. Weale, D.F. The Ministry of the Reverend Donald McDonald on Prince Edward Island, 1826-1867. Ph.D. Thesis, Queen's U., 1977.

Mélançon, Mgr Georges (1886- ). See : 6A. Chicoutimi-Bélanger.

Minville, M. Esdras. “M. Esdras Minville : 1896-1975”, L'Action Nationale, LXV, 9-10 (mai-juin, 1976). Numéro spécial.

Moncoq, Rev. Michel. Scollard, Robert, C.S.B. A Young and Holy Priest : The Life of Rev. Michel Moncoq, 1827-1856. Toronto: U. of St. Michael's College, 1979, Pp. 28.

Moodie, Susanna. ShIEldS, Carol. Susanna Moodie : Voice and Vision. Montreal : Borealis, 1977. Pp. 81.

Murray, Athol. Gorman, Jack. Pere Murray and the Hounds. Sidney : Gray's Pub., 1977. Pp. 184, ill.

Oliver, Rev. G.L. See : 2. Sermons, correspondence ...

Paré, Mgr Marius (1903- ). See : 6A. Chicoutimi-Bélanger.

Parker, Ammi J. Walkington, Douglas. "The Memoirs of Ammi J. Parker of Danville, Quebec", The Canadian Methodist Historical Society, Papers, 1978. Pp. 18. (Available, U.C.C.A.). 
Racine, Mgr Dominique (1828-1888). See : 6A. Chicoutimi-Bélanger.

Raimbault, Yvan. MaRTin, Louis. Yvan Raimbault, curé à Nicolet, 18061841. Thèse de M.A., U. de Montréal, 1977. Pp. 144.

Réboul, le R.P. Louis-Étienne. Bourgoin, Louis-Marie. "Le R.P. LouisÉtienne Réboul, fondateur de la ville de Hull”, Asticou, 18 (déc., 1977) 9-13.

Réticius, Frère, F.E.C. DE Lagrave, François. Frère Réticius, F.E.C. Le mandat tumultueux d'un visiteur provincial, 1880-86. Thèse de M.A., U. Laval, 1976. Pp. xiv, 228.

Riel, Louis. See : 8B. Woodsworth-Klassen.

MARTEL, Gilles. "Iouis Riel : ferveur nationaliste et foi religieuse", Relations, 425 (avril, 1977) 103-106.

Rundle, Rev. Robert.

DemPSEY, Hugh A., ed. The Rundle Journals. Calgary : Alberta Records Publications Board et al., 1978. Pp. 472.

Hutchinson, Gerald M. “Robert Terrill Rundle, 1811-1896”, Canadian Methodist Historical Society, Papers, 1978. Pp. 11. (Available, U.C.C.A.).

Savard, Mgr Félix-Antoine. Vachon, André. "Deux Saguenéens illustres ..." Saguenayensia, 19,1 (1977) 15-16.

Shields, Thomas T. Allyn, Russell C. "Thomas Todhunter Shields, Canadian Fundamentalist”, Ontario History, 70,4 (Dec., 1978) 263-280.

Strachan, John. Phelps, Dorothy J. John Strachan Comes to Cornwall, 18031813. 2nd ed. Cornwall, Ont. : Vesta Publications, 1976. Pp. 56, ill., index.

Sweet, H.C. KYDD, Ronald. "H.C. Sweet : Canadian Churchman", Journal of the Canadian Church Historical Society, 20, 1-2 (1978) 19-30.

Symonds, Herbert. Ruggle, Richard. "Herbert Symonds and Christian Unity", Journal of the Canadian Church Historical Society, 18,2-3 (1976) 53-83.

Tremblay, Mgr Victor. Vachon, André. "Deux Saguenéens illustres..., Saguenayensia, 19,1 (1977) 17-18.

Vandersteene, Fr. Rogier, O.M.I. Gregoret, Gene. "Father Rogier Vandersteene, o.m.i.: The Moccasin Priest", Western Canadian Journal of Anthropology, 6,4 (1976) 3-6.

Wilkinson, C.R.H. See : 10. Wilkinson.

Woodsworth, J.S. Klassen, William. "Two Wise Men From the West : Canadian Identity and Religion", in: Religion and Culture in Canada. Waterloo: Wilfrid Laurier U. Press, 1977. Pp. 271-288.

Young, Rev. Egerton Ryerson. See : 2. Records and papers. 


\section{RELIGIOUS PRACTICE AND PASTORAL CARE}

See : 5B. Quaker-Keyes.

Baillargeon, Noël. Le Séminaire de Québec de 1685 à 1760. Québec : U. Laval, 1977. Pp. 459.

Bilodeau, Rosario et Gisèle Morin. "La vie religieuse", collection Histoire nationale. Montréal : Éditions Hurtubise HMH. 1977. Pp̣. 30.

BIRD, Fred. "A Comparative Analysis of the Rituals Used by Some Contemporary 'New' Religious and Para-Religious Movements", in: Religion and Culiure in Canada. Waterloo: Wilfrid Laurier U. Press, 1977. Pp. 447-470.

Carpentier, Paul. "La survivance des croix de chemin : mythe ou réalité", Culture et tradition, 1 (1976) 48-53.

Chiasson, Anselme. "Cantiques acadiens de 1975", La Société historique acadienne - Les Cahiers, 8,1 (1977) 35-41.

HuRTUBise, R.P. Pierre, o.m.i. "L'origine sociale des vocations canadiennes de Nouvelle-France”, Sessions d'étude, 45 (1978) 41-56.

JАCOB, Jean-Noël. "Nos traditions, la messe dans les chantiers", Asticou, 20 (déc., 1978) 67-69.

Klan, Yvonne. "The Shakers", Raincoat Chronicles, 7 (1977) 20-24, ill.

Klymasz, Robert. "Speaking at/about/with the Dead: Funerary Rhetoric Among Ukrainians in Western Canada", Canadian Ethnic Studies, VII, 2 (1975) 50-56.

La Belle, Ronald. "L'eau de Pâques : coutume religieuse populaire", Culture et tradition, 2 (1977) 1-11.

Langlols, Michel. "Cahier de la confrérie de Sainte-Anne de 1657 à 1723", L'Ancêtre, 3.9 (1977) 357-405.

Lechasseur, Antonio. "Les pèlerinages de Sainte-Anne-de-la-Pointe-au-Père : reflet d'une mentalité religieuse", Revue d'histoire du Bas Saint-Laurent, 3,1 (1976) 22-26.

Lessard, Pierre. "L'imagerie de dévotion populaire de petit format", Culture et tradition, 2 (1977) 21-34.

Marcil, Claude. "Le schisme de la Saint-Valentin", L'Actualité, 2,2 (1977) 33-34, 51. (Sur la conversion au protestantisme des habitants du Grand rang de Girondville, au Lac St-Jean, dans les années '30).

McIntyre, Paul. Black Pentecostal Music in Windsor. Canadian Centre for Folklore Studies, Paper 15. Ottawa : National Museums of Canada, 1976. Pp. 120.

Morin, Louise. "Comment vivaient nos ancêtres", Québec-Histoire, 2,1 (automne, 1972) 45-54. 
OuRy, G.-M. "Le recueil des retraites des Ursulines de Québec”, Église et théologie, 9,2 (1978) 271-290.

Rodrigue, Denise. Le cycle de Pâques au Québec et dans l'ouest de la France. Thèse de D. ès L., U. Laval, 1976. Pp. xi - 586.

RoMPRÉ, Édouard. L'image de Dieu dans la tradition catéchétique canadienne. Thèse M.A., U. de Montréal, 1972.

SimARD, Jean. Une iconographie du clergé français au XVIIe siècle. Les dévotions de l'école française et les sources de l'imagerie religieuse en France et au Québec. Québec : U. Laval, 1976. Pp. xxiii, 264.

Trude, Marcel. "L'homme de ma génération, homme d'Ancien Régime", RUO, 47,3 (1977) 251-269.

Turnbul, Elsie G. "Pioneer Christmas in the Kootenays", B.C. Outdoors, 33,5 (1977) 54-59.

ZezulKa, J.M. "The Pastoral Vision in Nineteenth-Century Canada", Dathousie Review, 57,2 (1977) 224-241.

\section{MISSIONS}

See : 6A. Nouvelle-France-Dubé ; 6B. Sainte-Marie-des-Hurons ; 8. Bickersteth ; 11B. Kozak.

Bmaux, Michel. "Culture et Découverte dans les Relations des Jésuites", XVII Siècle, 112 (1976) 3-30.

Coster ScoviL, G.C. "M.S.C.C. and My China Experience”, Journal of the Canadian Church Historical Society, 19,3-4 (1977) 182-185.

Duff, Wilson. The Indian History of British Columbia: Volume 1: The Impact of the White Man. Victoria : British Columbia Provincial Museum, 1974. Pp. 117, ill. Reprint.

FISHER, Robin. Contact and Conflict: Indian and European Relations in British Columbia, 1774-1890. Vancouver : U. of British Columbia Press, 1977. Pp. xviii, 250.

Goosen, N. Jaye. "Missionary - Indian - Trader: The Triangular Nature of Contact in Rupert's Land", D.A. MuISE, Approaches to Native History in Canada: Papers of a Conference Held at the National Museum of Man, 1975. Ottawa : National Museums of Canada, 1977. Pp. 30-43.

Gray, Viviane. "The Words and Thoughts of Noel Knockwood on Micmac Religion and Cultural Ways Prior to European Contact", Tawow, 5,2 (1976) 38-39.

GYGER, Tony. L'influence des relations franco-iroquoises sur les missions des Cinq-Cantons. Thèse M.A., U. de Montréal, 1977.

Hill, Beth. "The Sisters of St. Ann", Alaska Journal, 7,1 (Winter, 1977) 41-45, ill. 
HURfORD, Grace Gibberd. "Missionary Service in China”, Journal of the Canadian Church Historical Society, 19,3-4 (1977) 177-181.

Inglis, Robert Runcie. A Critical Analysis of the Reconstruction of the Jesuit Mission of Ste. Marie des Hurons. M. Museal. U. of Toronto, 1972.

Jaenen, Cornelius J. "Missionary Approaches to Native Peoples", D.A. Muise, Approaches to Native History in Canada: Papers of a Conference Held at the National Museum of Man, 1975. Ottawa : National Museums of Canada, 1977. Pp. 5-15.

LAMIRANDE, Émilien. "Traditions orales du XIXe siècle sur la présence de prêtres espagnols en Colombie-Britannique", RUO, 47,4 (1977) 393-412.

LanglaIs, Jacques. Les Jésuites Canadiens-Français en Chine (1918-1955) Leur perception des traditions chinoises. Thèse Ph.D., McMaster U., 1977.

L'ESSARD, Claude. "L'aide financière de l'Église de France à l'Église naissante du Canada", RUO, 47,1-2 (1977) 162-181.

Lillard, Charles, ed. Mission to Nootka, 1874-1900: Reminiscences of the West Coast of Vancouver Island. Sidney, B.C. : Gray's Publishing, 1977. Pp. 120.

Little, J.I. "Missionary Priests in Quebec's Eastern Townships: The Years of Hardship and Discontent, 1825-53", Study Sessions, 45 (1978) 21-36.

McGeachie, Pixie. "Father Pandosy's Mission", Westworld, 2,5 (1976) 42,4548.

Mrllman, T.R. "The Domestic and Foreign Missionary Society of the Church of England in Canada, 1883-1902", Journal of the Canadian Church Historical Society, 19,3-4 (1977) 166-176.

Ruggle, Richard E. "A House Divided Against Itself : The Denominational Antagonisms of the Grand River Missions", The Canadian Society of Church History Papers, 1978. Pp. 1-10.

Sarnia Indian Series. "Reports of Missionaries on Sarnia and Walpole Island Reserves as Reported in Appendix $T$ of the Journals of the Legislative Assembly, 1847". Sarnia Indian Series No. 7. Bright's Grove, Ont : G. Smith, 1977. Pp. 5.

SURTEES, R.J. "The Changing Image of the Canadian Indian : An Historical Approach", D.A. MUISE, Approaches to Native History in Canada: Papers of a Conference Held at the National Museum of Man, October, 1975. Ottawa: National Museums of Canada, 1977. Pp. 111-125.

ThérIault, Léon. "Les missionnaires et leurs paroissiens dans le Nord-Est du Nouveau-Brunswick, 1766-1830", Revue de l'Université de Moncton, 9,1-3 (1976) 31-52.

Tissot, Georges. "De la Chute d'Ate au Dragon Volant : Un mythe iroquois au XVIII siècle", in: P. Slater, ed., Religion and Culture in Canada. Waterloo : Wilfrid Laurier U. Press, 1977. Pp. 65-80. 
VeCsey, Christopher T. Traditional Ojibwa Religion and its Historical Changes. Ph.D. Thesis, Northwestern U., 1977. Pp. 283. University Microfilms, 7800759.

VeILletTe, John and Gary White. Early Indian Village Churches: Wooden Frontier Architecture in British Columbia. Vancouver: U.B.C. Press, 1977. Pp. 184, ill.

Wilkinson, C.R.H. "Missionary Service in Northern India", Journal of the Canadian Church Historical Society, 19,3-4 (1977) 186-189.

\section{SPECIAL PROBLEMS}

A. The Church and the Arts

See : 7. Gauthier.

Boisclaire, Marie-Nicole. Hôtel-Dieu de Québec/Catalogue des peintures. Québec : Ministère des Affaires culturelles, 1977. Pp. 195.

CARrière, Georges-E. "La peinture religieuse de Jean Dallaire", Asticou, 17 (avril, 1977) 3-8.

De Serres, Mme et Andrée Boileau. "L'art religieux au Musée historique de Vaudreuil", Sessions d'étude, 45 (1978) 57-70.

Gagnon, F.-Marc et Nicole Clouthier. Premiers peintres de la NouvelleFrance, tome 1. Col. Civilisation du Québec no. 16, Ministère des Affaires culturelles, 1976. Pp. 164.

Kalman, Harold D. "The Development of Religious Architecture in Ontario", in: H. Kalman, The Conservation of Ontario Churches. Toronto : Ministry of Culture and Recreation, 1977. Pp. 103-113.

NOPPEN, Luc. Évaluation de l'architecture religieuse en Nouvelle-France : le rôle des modèles architecturaux", Journal of Canadian Art History/ Annales de l'art canadien, 4,1 (1977) 45-60.

Ostiguy, Jean-René. "Charles Huot raconte les miracles de Saint Antoine de Padoue", Vie des Arts, 22,87 (1977) 16-17.

PAGÉ, Norman. "La quadrature du cercle en architecture religieuse", in: Religion and Culture in Canada, Waterloo : Wilfrid Laurier U. Press, 1977. Pp. 421-446.

PorTer, John R. and Léopold Désy. "Deux facettes du mimétisme en sculpture ancienne du Québec", Québec Histoire, 2,2 (1973) 61-66.

Shack, Sybil. "The Education of Immigrant Children During the First Two Decades of This Century", Historical and Scientific Society of Manitoba, Transactions, Series III, 30 (1973-74) 17-32.

SHENK, Alfred J. "Wayside Crosses", (Maryhill, Ont.), Waterloo Historical Society, 65 (1977) 44-54.

Trask, Deborah. Life How Short, Eternity How Long. Halifax : Nova Scotia Museum, 1978. Pp. 100. (Nova Scotia tombstone carving). 


\section{B. The Church and Education}

See : 7. de Valk.

ALEXANDRE, Marie-Jeanne. Les religieuses enseignantes dans le système d'éducation du Québec. Québec: Cahiers d'ISSH, U. Laval, 1977. Pp. 137.

CARney, R.J. Relations in Education Between the Federal and Territorial Governments and the Roman Catholic Church in the Mackenzie District, North West Territories, 1867-1961. Ph.D. Thesis, U. of Alberta, 1971. Pp. 686.

Classen, Hans George. "Religious Studies in Canada", Queen's Quarterly, 85,3 (1978) 389-402.

FarIS, Ron. The Passionate Educators: Voluntary Associations and the Struggle for Control of Adult Educational Broadcasting in Canada, 1919-52. Toronto: Peter Martin Associates, 1975. Pp. xvi, 202.

Galarneau, Claude. "L'enseignement des sciences au Québec et Jérôme Demers (1765-1835)", RUO, 47,1-2 (1977) 84-93.

Greer, Allan. "The Pattern of Literacy in Quebec, 1745-1899", Histoire sociale - Social History, XI,22 (1978) 293-335.

HaRris, Robin S. A History of Higher Education in Canada, 1663-1960. Toronto : U. of Toronto Press, 1976. Pp. xxiv, 715.

JACKSON, James A. "Railways and the Manitoba School Question", Historical and Scientific Society of Manitoba, Transactions, Series III, 30 (197374) 81-88.

JARrell, R.A. "The Rise and Decline of Science at Quebec, 1824-1844", Histoire Sociale/Social History, 19 (mai, 1977) 77-91.

KozaK, Kathryn. Education and the Blackfoot: 1870-1900. M.A. Thesis, U. of Alberta, 1971.

Lyons, John. "The (Almost) Quiet Evolution : Doukhobor Schooling in Saskatchewan", Canadian Ethnic Studies, VIII,1 (1976) 23-37.

Macdonald, Robert James. "Hutterite Education in Alberta: A Test Case in Assimilation, 1920-1970", Canadian Ethnic Studies, VIII,1 (1976) 9-22.

OKE, Edward Lawrence. A Philosophy of Bible College Education. M.Ed., U. of Calgary, 1972.

Prentice, Alison. The School Promoters : Education and Social Class in MidNineteenth Century Upper Canada. Canadian Social History Series. Toronto : McClelland and Stewart Ltd., 1977.

Rusak, Stephen. Archbishop Adélard Langevin and the Manitoha School Question, 1895-1915. Ph.D. Thesis, U. of Alberta, 1975.

-. Relations in Education Between Bishop Legal and the Alberta Liberal Government, 1905-1970. M.A. Thesis, U. of Alberta, 1966.

Savoie, Alexandre-J. "Les écoles du Nouveau-Brunswick avant 1871", La Société historique acadienne, Les Cahiers, 8,4 (1977) 179-189. 
ShaffIR, William. "The Organization of Secular Education in a Chassidic Jewish Community", Canadian Ethnic Studies, VIII,1 (1976) 38-51.

White, Clinton O. "Language, Religion, Schools and Politics Among Catholic German-American Settlers in St. Peter's Colony, Saskatchewan, 19031916", Study Sessions, 45 (1978) 81-100.

\section{The Church and Immigration and Settlement}

See : 6A. Port Arthur-MacDonald.

Barber, M.J. The Assimilation of Immigrants in the Canadian Prairie Provinces, 1896-1918: Canadian Perception and Canadian Policies. Ph.D. Thesis, King's College, U. of London, 1975.

Campeau, Lucien. "Le commerce des clercs en Nouvelle-France", RUO, 47.1-2 (1977) 27-35.

Ishwaran, K. Family, Kinship and Community: A Study of Dutch Canadians. Toronto : McGraw-Hill Ryerson Ltd., 1977. Pp. 181.

KaZYMYra, Nadia O.M. "The Defiant Pavlo Krat and the Early Socialist Movement in Canada", Canadian Ethnic Studies, 10,2 (1978) 38-54.

Kotr, Teresa and Jerzy A. WoJciechowski, eds. Polonia of Tomorrow. Toronto: Canadian Polish Conference, n.d.

Kurlents, Alfred, ed. Eelasted Kanada : Ajolooline Kogueteos. (The Estonians in Canada: An Historical Symposium). Toronto: Estonian Historical Commission of Canada, 1975. Pp. 670.

Ludwig, William. "Pioneering Memoirs : 1903", Chelsea Journal, 4,4 (JulyAugust, 1978) 177-193. (re Saskatchewan pioneers).

Mannion, John J., ed. The Peopling of Newfoundland: Essays in Historical Geography. St. John's: Institute of Social and Economic Research. Memorial U., Economic Papers No. 8. Pp. 289.

Osborne, Brian S., ed. The Settlement of Canada: Origins and Transfer: Proceedings of the 1975 British-Canadian Symposium on Historical Geography. Kingston, Ont. : Queen's U. Press, 1976. Pp. xi, 239, ill., maps.

Painchaud, Robert. "French-Canadian Historiography and Franco-Catholic Settlement in Western Canada, 1870-1915", C.H.R., 59,4 (1978) 447-466.

Potrebenko, Helen. No Strects of Gold: A Social History of Ukrainians in Alberta. Vancouver: New Star Books, 1977. Pp. 31.

Richtik, James and Danny Hutch. "When Jewish Settlers Farmed in Manitoba's Interlake Area", Canadian Geographical Journal, 95,1 (1977) 32-35.

Wilson, Keith and James B. Wendalls. The Belgians in Manitoba. Winnipeg : Pegius Publishers Ltd., 1976. Pp. 97.

Wukasch, Peter. "Baltic Immigrants in Canada", Concordia Historical Institutc Quarterly, 50 (Spring, 1977) 4-22. 


\section{The Church and Politics}

See : 5B. Anglican-Gabbert; 6B. Red River-Pannekoek; 8. Briand-Brunet.

Allen, Richard. "The Social Gospel as the Religion of the Agrarian Revolt", in: Carl Berger and Ramsay Cook, eds., The West and the Nation, Toronto : McClelland and Stewart, 1976. Pp. 174-186.

Armstrong, Christopher and H.V. Nelles. The Revenge of the Methodist Bicycle Company : Sunday Streetcars and Municipai Reform in Toronto. 1888-1897. Toronto: Peter Martin Associates, 1977. Pp. x, 214.

Baum, Gregory. "The Contemporary Social Gospel", Papers of the Institute for Christian Life in Canada. Toronto, 1978. Pp. 1-18.

- "Political Theology in Canada", The Ecumenist, 15,3 (1977) 33-46.

-. "Political Theology in Canada", in: G. BAum, The Social Imperative. New York: Paulist Press, 1979. Pp. 70-98.

-. "Social Catholicism in Nova Scotia: The Thirties", in: P. Slater, ed., Religion and Culture in Canada. Waterloo: Wilfrid Laurier U. Press, 1977. Pp. 117-148.

BeleC, Jacques. La pensée socio-économique de l'Association catholique de la jeunesse canadienne-française, 1904-1935. Thèse M.A., U. de Montréal, 1972.

Campeau, Lucien. "Le rôle de l'Église et sa ligne de conduite dans la formation de la Nouvelle-France", Asticou, 16 (sept., 1976) 53-59.

COMEAU, Robert et al. L'Action politique des ouvriers québécois, fin du XIX ${ }^{e}$ siècle à 1919 : recueil de documents. Coll. Histoire des travailleurs québécois, 4. Montréal : U. du Québec, 1976. Pp. xiv, 176.

Dandurand, Jean. Les syndicats catholiques dans le secteur des pâtes et papiers et la société québécoise de 1900 à 1930. Thèse de M. Sc. Soc., U. Laval, 1976. Pp. 228.

—. "Depuis 1960 : l'Église et les chrétiens dans l'histoire du mouvement ouvrier au Québec", Relations, 398 (1974) 293-297.

Doyle, Kevin Anthony. "Fenianism in North America : A Problem in AngloCanadian Relations 1860-1870". M.A. Thesis, Dalhousie, 1976. Pp. v,145. Canadian Theses on Microfiche, No. 28872.

Driedger, Leo and William H. Form. "Religious Typology and the Social Ideology of the Clergy", International Journal of Comparative Sociology, 12,1-2 (1976) 1-18.

Hatton, G. Russell. "Ecumenism, Justice and the Northern People", The Ecumenist, 15,2 (1977) 28-32.

Haverluck, Bob. "The Grim Reaping: Patterns of Racism in the Prairie Region", Papers of the Institute for Christian Life in Canada. Toronto, 1978. Pp. 66-91.

Hogan, Brian F., c.s.b. "The Guelph Novitiate Raid : Conscription, Censorship and Bigotry During the Great War", Study Sessions, 45 (1978) 57-80. 
Kerans, Patrick. "Punishment vs. Reconciliation: Retributive Justice and Social Justice in the Light of Social Ethics in Canada", in: Religion and Culture in Canada.. Waterloo : Wilfrid Laurier U. Press, 1977. Pp. 225-270.

Larose, G. "Christians Who Chose Marxism", Papers of the Institute for Christian Life in Canada. Toronto, 1978. Pp. 57-62.

McGrath, Des. "Action Forum - The Atlantic Region", Papers of the Institute for Christian Life in Canada. Toronto, 1978. Pp. 40-57. (Newfoundland fisheries and unions, 1960's - 70's).

McLaren, Angus. "Birth Control and Abortion in Canada, 1870-1920", C.H.R., 59,3 (1978) 319-340.

Nelles, H.V. and Christopher ARMSTrong. "The Great Fight for Clean Government", Urban History Review/Revue d'histoire urbaine, 2 (oct., 1976) 50-66.

Sacouman, R. James. "Underdevelopment and the Structural Origins of Antigonish Movement Co-operatives in Eastern Nova Scotia", Acadiensis, 7,1 (1977) 66-85.

St-Amant, Jean-Claude. L'école sociale populaire et le syndicalisme catholique, 1911-1949. Thèse de M.A., U. Laval, 1976. Pp. xii, 99.

St-ONGE, Jacques. L'opinion de la presse anglo-québécoise et l'élection fédérale de 1896. Thèse de M.A., U. de Montréal, 1975. Pp. 185.

SILVER, Arthur. "French Quebec and the Métis Question, 1869-1885", in: Carl Berger and Ramsay Cook, eds., The West and the Nation, Toronto : McClelland and Stewart, 1976. Pp. 91-113.

Tномson, John Howard. Mackenzie Bowell : Orangeman and Politician, 1867. 1896. M.A. Thesis, U. of Guelph, 1972.

VANDERKLOet, Edward, ed. A Christian Union in Labour's Wasteland. Toronto: Wedge Publishing Foundation, 1978. Pp. 1-139. (Essays on the Christian Labour Association of Canada).

Williams, John R. "Religion in Newfoundland: the Churches and Social Ethics", in: P. Slater, ed., Religion and Culture in Canada. Waterloo : Wilfrid Laurier U. Press, 1977. Pp. 95-116.

\section{E. The Church and Society}

See : 6B. Hébertville; 11D. Baum-Social Imperative.

Allen, Richard, ed. Religion and Society in the Prairie West. Col. Canadian Plains Studies no. 3. Regina : U. of Regina, 1974. Pp. 110.

BacchI, Carol. "Race Regeneration and Social Purity. A Study of the Social Attitudes of Canada's English-Speaking Suffragists", Histoire Sociale Social History, XI,2 (Nov., 1978) 460-474. 
BeHIELS, Michel. "L'Association catholique de la jeunesse canadienne-française and the Quest for a Moral Regeneration, 1903-1914", JCS/REC, 13,2 (1978) 27-41.

Buller, Herman. "The Jews : Nationalism and Quebec Independence", Canadian Jewish Outlook, 11,3 (March, 1973) 8-10.

CARTER, John C. "Temperance and Local Option in Bruce and Grey Counties", in: The Bruce County Historical Society Year Book, (1976). Pp. 21-25.

Clifford, Keith. "His Dominion: A Vision in Crisis", in: P. Slater, ed., Religion and Culture in Canada. Waterloo: Wilfrid Laurier U. Press, 1977. Pp. 23-42.

Cooke, Michael. "The Christian Movement for Peace”, The Ecumenist, 16,2 (1978) 28-31.

Coward, Harold. "Religion And Ethnicity : An Overview of Issues Raised", in: H. Coward and L. Kawamura, eds., Religion and Ethnicity. Waterloo: Wilfrid Laurier U. Press, 1978. Pp. 171-181.

Crysdale, Stewart. "The Place of Religion in Ontario in the Twentieth Century", in: H. Kalman, The Conservation of Ontario Churches. Toronto: Ministry of Culture and Recreation. Pp. 69-82.

DesPland, Michel. "Religion and the Quest for a National Identity: Problems and Perspectives", in: Reiigion and Culture in Canada. Waterloo: Wilfrid Laurier U. Press, 1977. Pp. 525-552.

DumaIs, Monique. "Féminisme et Religion au Québec", in: Religion and Culture in Canada. Waterloo: Wilfrid Laurier U. Press, 1977. Pp. 149186.

Felske, Lorry U. Science and the Radical Social Gospel in Western Canada. M.A. Thesis, U. of Calgary, 1975. Pp. vi, 144.

Gagnon, Serge. "Le rôle socio-politique de l'Église et la religion catholique après la Conquête, ou comment assurer la paix sociale", Asticou, 22 (sept., 1976) 22-30.

GoA, David. "Secularization Among Ethnic Communities in Western Canada", in: Harold Coward and Leslie Kawamura, eds., Religion and Ethnicity, Waterloo: Wilfrid Laurier U. Press, 1978. Pp. 1-20.

Grant, John Webster. "Religion and the Quest for a National Identity: The Background in Canadian History", in: P. Slater, ed., Religion and Culture in Canada. Waterloo: Wilfrid Laurier U. Press, 1977. Pp. 7-22.

HARDY, René. "L'origine des zouaves pontificaux canadiens", Les zouaves pontificaux canadiens. "Coll. Mercure - Histoire", no. 19. Ottawa : Musées nationaux du Canada, 1976. Pp. 1-67.

Headon, Christopher. "Women and Organized Religion in Mid and Late Nineteenth Century Canada", Journal of the Canadian Church Historical Society, 20,1-2 (1978) 3-18. 
Hemmerick, William J. "The Funding of Religious Properties and the Law of Ontario", in: H. Kalman, The Conservation of Ontario Churches. Toronto: Ministry of Culture and Recreation, 1977. Pp. 83-102.

Henson, Tom M. "Ku Klux Klan in Western Canada", Alberta History, 24,4 (1977) 1-8.

Hutchinson, Roger. "Religion, Ethnicity and Public Policy", in: H. Coward and L. KaWamura, eds., Religion and Ethnicity, Waterloo: Wilfrid Laurier U. Press, 1978. Pp. 135-151.

-. "Religion, Morality and Law", in: Religion and Culture in Canada. Waterloo : Wilfrid Laurier U. Press, 1977. Pp. 187-224.

LemieuX, Lucien et Jean-Pierre Langlors. "Le clergé et les troubles de 1837", Asticou, 16 (sept., 1976) 38-52.

Mawer, David R. The Return of the Catholic Past: The Debate Between François-Xavier Garneau and His Critics, 1831-1945. Ph.D. Thesis, McGill U., 1977.

Ouellet, Fernand. "Le rôle du clergé durant les troubles de 1837-38", Asticou, 16 (sept., 1976) 31-37.

Robinson, Lois Mary. Les Mélanges religieux et la littérature. Thèse de M.A., U. Laval, 1976. Pp. iv, 130.

Strople, Margaret J. Campbell. Prohibition and Movements of Social Reform in Nova Scotia, 1894-1920. M.A. Thesis, Dalhousie U., 1975. Pp. iii, 180.

Ward-Harris, E.D. A Nun Goes to the Dogs. Victoria : Sono Nis Press, 1977. Pp. 136, ill.

Williams, Cyril. "Religion and Welsh Nationality", in: H. CoWARD and L. KaWAMURA, eds., Religion and Ethnicity. Waterloo : Sir Wilfrid Laurier U. Press, 1978. Pp. 151-170. 